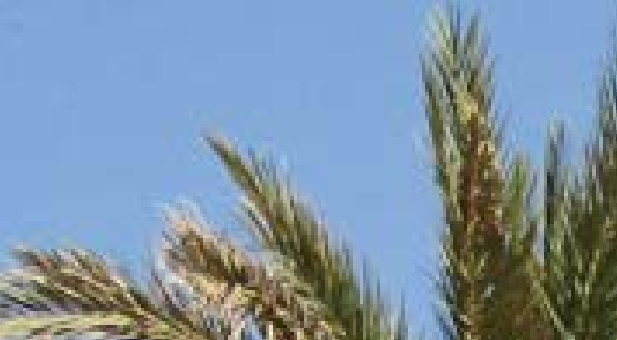

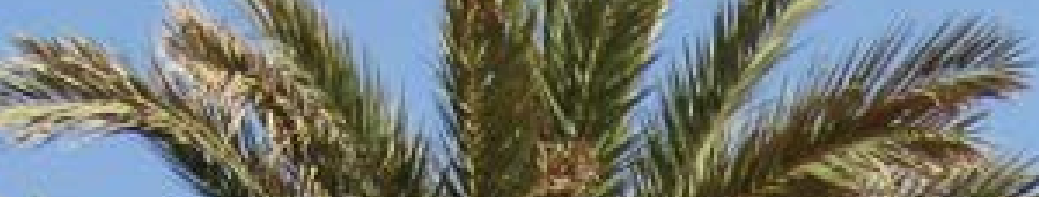

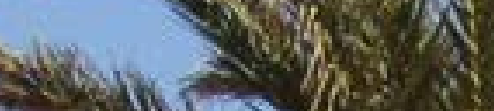

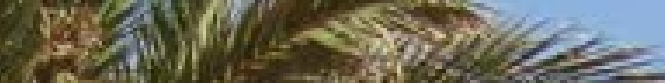

S.

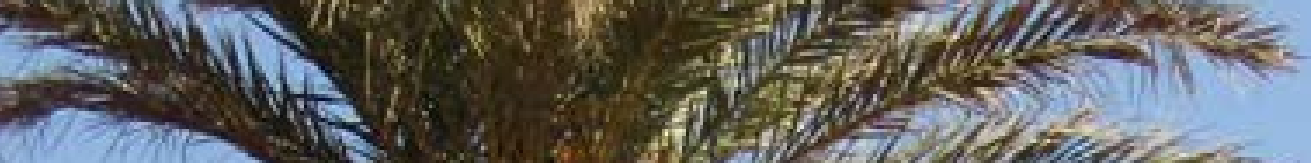
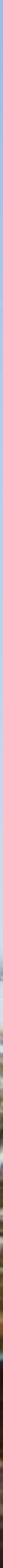
Restoration of the Marabout of Sidi Abdullah Khalifa at Ouled Youssef, M'hamid Oasis, Morocco

\section{Restauración del morabito de Sidi Abdullah Khalifa en Ouled Youssef, Oasis de Mhamid, Marruecos}

Restauração do marabu de Sidi Abdullah Khalifa em Ouled Youssef, Oásis de Mhamid, Marrocos

\section{Marta Colmenares Fernández, Alejandro García Hermida, Carmen Moreno Adán}

\section{Background}

The restoration of the marabout shrine of Sidi Abdullah Khalifa is one of various actions undertaken by the Terrachidia association since 2012 at the M'hamid Oasis, the last and southernmost oasis in the Draa valley in Zagora province, Morocco.

This work has sought to preserve, study, disseminate and continue the tangible and intangible heritage of the oasis dwellers. Although its ultimate aim is to help preserve the traditional local knowledge that over centuries allowed the cultural landscape of such oases to be created and transformed, this has been pursued by means of restoring, recovering or rebuilding various of their public spaces and architectural features with heritage value. These notably include the gateways to eleven of the twelve traditional walled ensembles (ksur) conserved at the oasis, along with mosques, streets and other communal buildings and spaces.

The neglect of traditional urban ensembles in certain rural settings along with policies and regulations encouraging people to leave them means that the regular maintenance needed by these architectures has
Antecedentes

La restauración del morabito de Sidi Abdullah Khalifa forma parte de las acciones emprendidas por la Asociación Terrachidia desde el año 2012 en el oasis de Mhamid, el último y más meridional oasis del valle del Draa, en la provincia de Zagora, Marruecos.

Estos trabajos han tenido como objetivos la conservación, el estudio, la difusión y la continuación del patrimonio material e inmaterial de las poblaciones de este oasis. Si bien su fin último ha sido contribuir a la conservación de los conocimientos locales tradicionales que permitieron crear $y$ transformar durante siglos el paisaje cultural de estos oasis, esto se ha emprendido a través de la restauración, la recuperación o la reconstrucción de diferentes espacios públicos y elementos arquitectónicos de valor patrimonial del oasis. Entre ellos, pueden destacarse las puertas de acceso del recinto amurallado de once de los doce conjuntos tradicionales ( $k$ sur) que se conservan en este oasis, así como mezquitas, calles y otros edificios y espacios comunitarios.

La falta de atención hacia los conjuntos urbanos tradicionales en determinados entornos rurales y las
Antecedentes

A restauração do marabu de Sidi Abdullah Khalifa forma parte das ações empreendidas pela Associação Terrachidia desde 2012 no oásis de Mhamid, o último e mais meridional oásis do vale do Draa, na província de Zagora, Marrocos.

Estes trabalhos tiveram como objetivos a conservação, o estudo, a difusão e a continuação do património material e imaterial das populações deste oásis. Embora a sua última finalidade tenha sido contribuir para a conservação dos conhecimentos locais tradicionais que permitissem criar e transformar durante séculos a paisagem cultural deste oásis, isto foi empreendida através da restauração, recuperação ou da reconstrução de diferentes espaços públicos e de elementos arquitetónicos de valor patrimonial do oásis. Entre eles, podemos destacar as portas de acesso ao recinto amuralhado de onze dos doze conjuntos tradicionais (ksur) que se conservam neste oásis, bem como as mesquitas, ruas e outros edifícios e espaços comunitários.

A falta de atenção para com os conjuntos urbanos tradicionais em determinados meios rurais e as políticas e normas que 
Terrachidia thus combines training for both local youth and domestic or foreign volunteers taking part in each intervention with the recovery of tangible and intangible heritage, development cooperation and awareness and outreach work on these projects, which also help preserve the place's identity.

To complement this documentation and dissemination of heritage, in 2018 we invited the team of ArCHIAM (Centre for the Study of Architecture and Cultural Heritage of India, Arabia and the Maghreb) at Liverpool University to participate in the restoration of the gateway to the ksar of Ouled Driss, in which fifteen architecture students from the university also took part. That positive experience led to a partnership and co-funding for another venture at the oasis: the restoration of the marabout shrine of Sidi Abdullah Khalifa.
Terrachidia aúna así formación tanto de los jóvenes locales como de los voluntarios nacionales e internacionales que participan en cada una de sus intervenciones, con la recuperación del patrimonio tangible e intangible, con la cooperación y con las acciones de sensibilización y difusión de los trabajos realizados, que contribuyen también a la mejor conservación de la identidad propia del lugar.

Como complemento a estas labores de documentación y difusión del patrimonio, en 2018 se invitó al equipo de ArCHIAM (Centre for the Study of Architecture and Cultural Heritage of India, Arabia and the Maghreb) de la Universidad de Liverpool a colaborar en ellas con motivo de la restauración de la puerta de acceso al ksar de Ouled Driss, en la que además participaron 15 estudiantes de arquitectura de esta universidad. La experiencia positiva abrió la puerta a la colaboración y la cofinanciación para otro proyecto en el oasis: la restauración del morabito de Sidi Abdullah Khalifa.
Terrachidia une assim a formação tanto de jovens locais como de voluntários nacionais e internacionais que participam em cada uma das suas intervenções, com a recuperação do património tangível e intangível, com a cooperação e com as ações de sensibilização e difusão dos trabalhos realizados, que contribuem também para a melhor conservação da identidade própria do local.

Como complemento a estes labores de documentação e difusão do património, em 2018 convidou-se a equipa de ArCHIAM (Centre for the Study of Architecture and Cultural Heritage of India, Arabia and the Maghreb) da Universidade de Liverpool para colaborar neles com motivo da restauração da porta de acesso ao ksar de Ouled Driss, no que também participaram 15 estudantes de arquitetura desta universidade. A experiência positiva abriu a porta para a colaboração e o cofinanciamento para outro projeto no oásis: a restauração do marabu de Sidi Abdullah Khalifa.

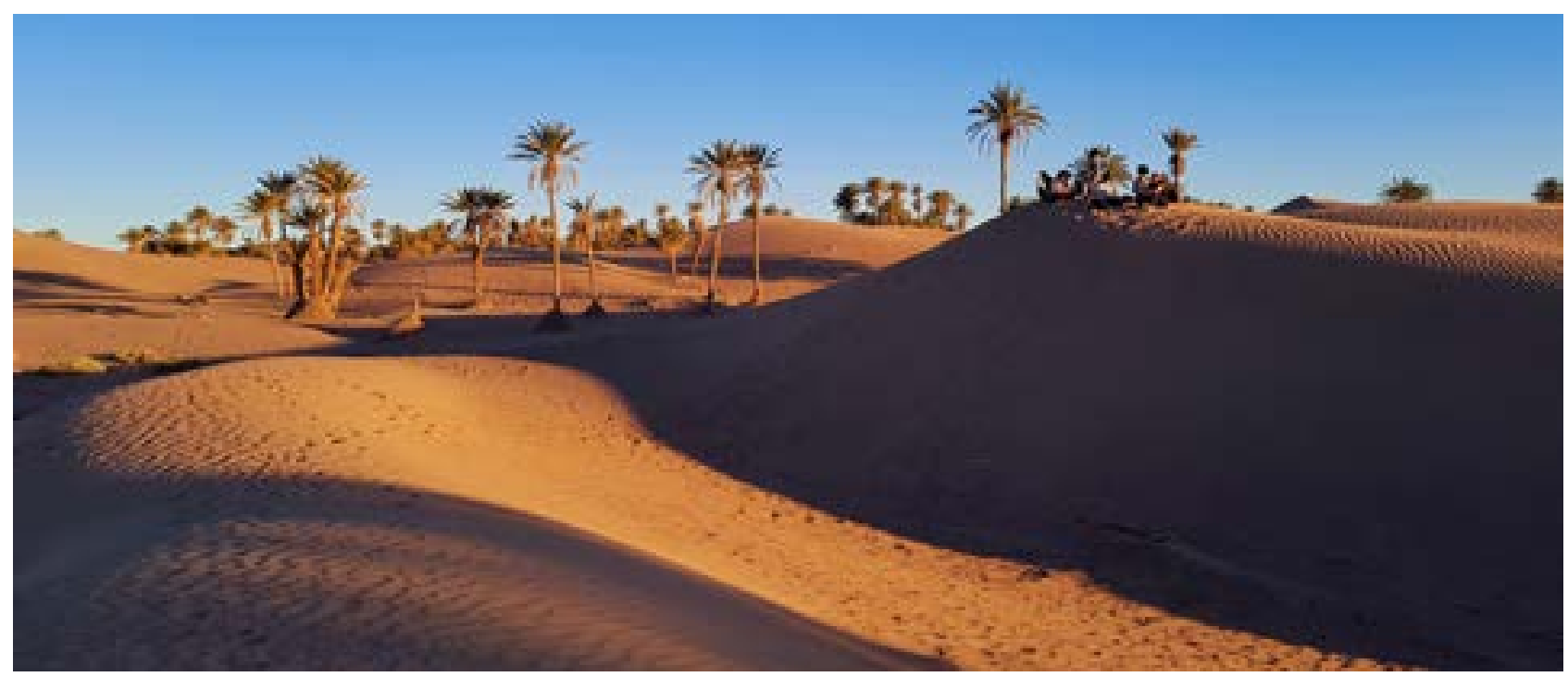




\section{The marabout of Sidi Abdullah Khalifa}

This shrine stands within a palm grove, by a water well, between the ksur of Ouled Youssef and M'hamid El Ghezlane. The marabout is one of the oasis's finest and most remarkable buildings, as well as a site appreciated and venerated by local people. It is the resting place of the holy man after whom it is named: Sidi Abdullah Khalifa, who is still renowned as he must have been in life as a spiritual guide and healer, especially of mental ailments.

It is a small building with a square plan, with sides of $7.8 \mathrm{~m}$ (15 cubits) and an area of just $40 \mathrm{~m} 2$, though there is also a long porch annexed to it as an anteroom. The floor of the square building is divided into nine modules. The central
El morabito de Sidi Abdullah Khalifa

El edificio se yergue en mitad de un palmeral, junto a un pozo de agua, entre los ksur de Ouled Yussef y Mhamid El Ghezlane. Este morabito es uno de los edificios más singulares y bellos de este oasis, además de un lugar apreciado y respetado por sus habitantes. En él descansan los restos del morabito que le da nombre, Sidi Abdullah Khalifa, quien ha conservado hasta hoy la reputación que debió tener en vida, de excelente guía espiritual y sanador, en especial de patologías psíquicas.

Se trata de un pequeño edificio de planta cuadrada, de 7,8 metros (15 codos) de lado y apenas 40 metros cuadrados, si bien se adosa a él un segundo espacio longitudinal que le sirve de antesala. La planta del edificio cuadrado está dividida
O marabu de Sidi Abdullah Khalifa

$O$ edifício ergue-se no meio de um palmeiral, junto a um poço de água, entre os ksur de Ouled Yussef e Mhamid El Ghezlane. Este marabu é um dos edifícios mais belos e singulares deste oásis, para além de ser um lugar apreciado e respeitado pelos seus habitantes. Nele descansam os restos do marabu que lhe deu o nome, Sidi Abdullah Khalifa, quem conservou até hoje a reputação que teve em vida, a de excelente guia espiritual e sanador, em concreto de patologias psíquicas.

Trata-se de um pequeno edifício de planta quadrada, de 7,8 metros (15 côvados) de largura e de apenas 40 metros quadrados, ainda que haja um segundo espaço longitudinal unido a este que lhe serve de antecâmara. A planta do edifício qua-

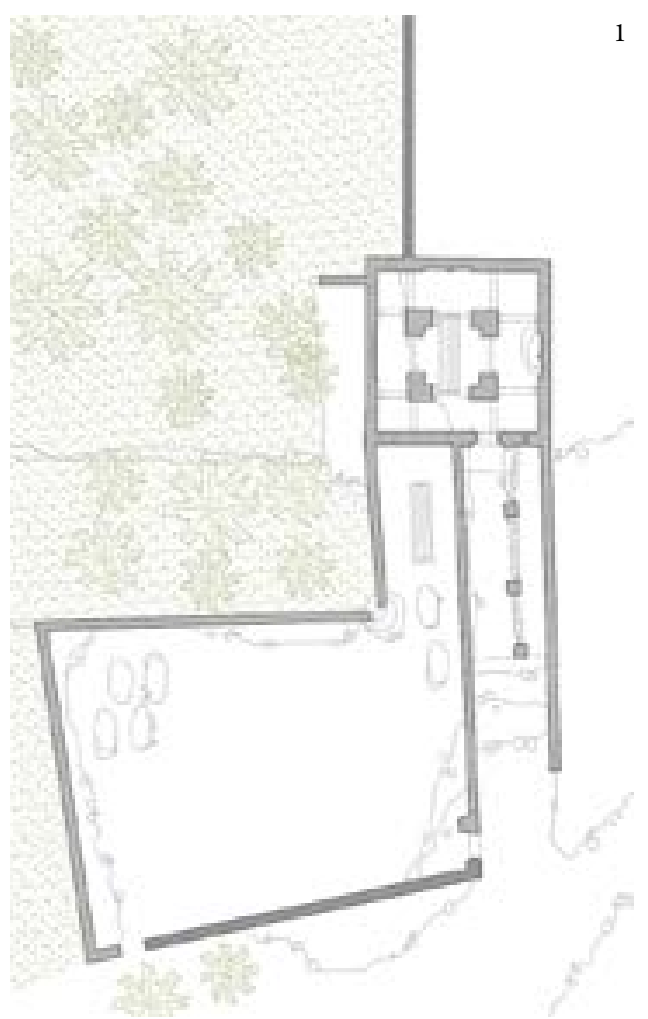

1: Plan of the Marabout 2: Ortophoto of the location |1: Planta del Morabito 2: Ortofoto del emplazamiento | 1: Planta do Marabu 2: Ortofotografia da localização (2: Google Earth)

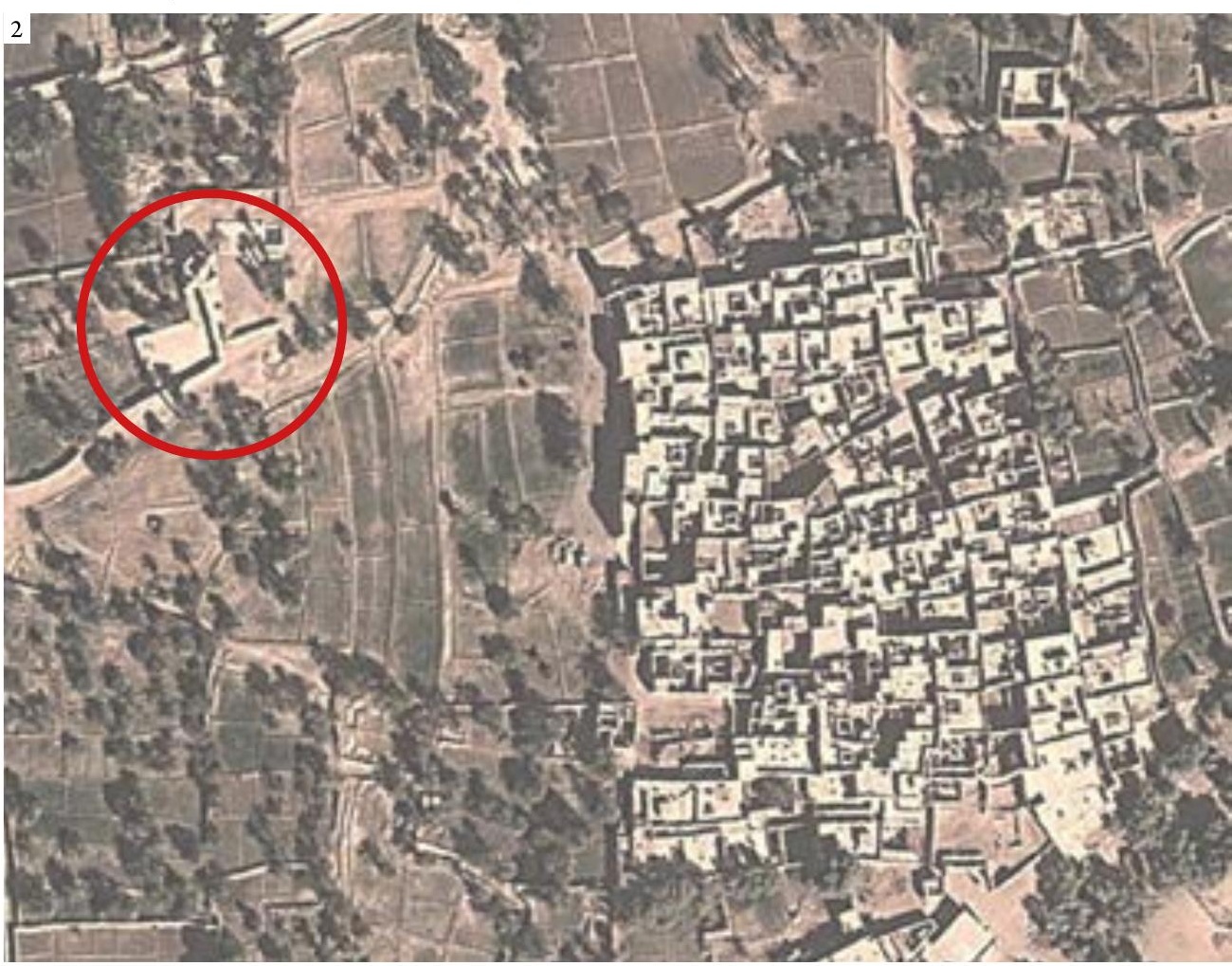


space contains the tomb, surrounded by an ambulatory. The anteroom gave shelter to those arriving on pilgrimage. The marabout is just one story high but the middle section rises above the rest of the main volume, which is in turn higher than the long porch. The main building, $5 \mathrm{~m}$ (9 cubits) high, is crowned by five parabolic domes rising from roof level, one over each corner module of the ambulatory and a larger one in the middle, raised over a cubic block with typically stepped corners. The ambulatory's four intermediate modules are simply covered with flat roofing, as is the anteroom. en nueve módulos. El espacio central alberga la tumba y un deambulatorio alrededor de éste. La mencionada antesala daba cobijo a quienes peregrinaban hasta el lugar. El morabito tiene una sola planta de altura, pero el espacio central se alza por encima del resto de la construcción principal, a su vez de mayor altura que el espacio longitudinal anejo. La construcción principal, de 5 metros (9 codos) de altura, está coronada por cinco cúpulas parabólicas que se alzan sobre esa cota: una sobre cada uno de los módulos de esquina del deambulatorio y otra de mayor altura en el centro, elevada sobre un tambor cúbico con remates de esquina típicamente escalonados. Los cuatro módulos intermedios del deambulatorio están sencillamente cubiertos por un forjado horizontal, como lo está también la antesala. drado está dividida em nove módulos. O espaço central, que alberga a tumba, e um deambulatório à volta deste. A mencionada antecâmara dava abrigo àqueles que peregrinavam até ao local. Este marabu tem apenas um piso de altura, mas o espaço central alça-se por cima do resto da construção principal, por sua vez mais alto do que o espaço longitudinal anexo. A construção principal, de 5 metros (9 côvados) de altura, está coroada por cinco cúpulas parabólicas que se alçam sobre essa cota: uma sobre cada um dos módulos de esquina do deambulatório e outra de maior altura no centro, elevada sobre um tambor cúbico com remates de esquina tipicamente escalonados. Os quatro módulos intermédios do deambulatório estão simplesmente cobertos com umaestrutura de madeira, como também o está a antecâmera.

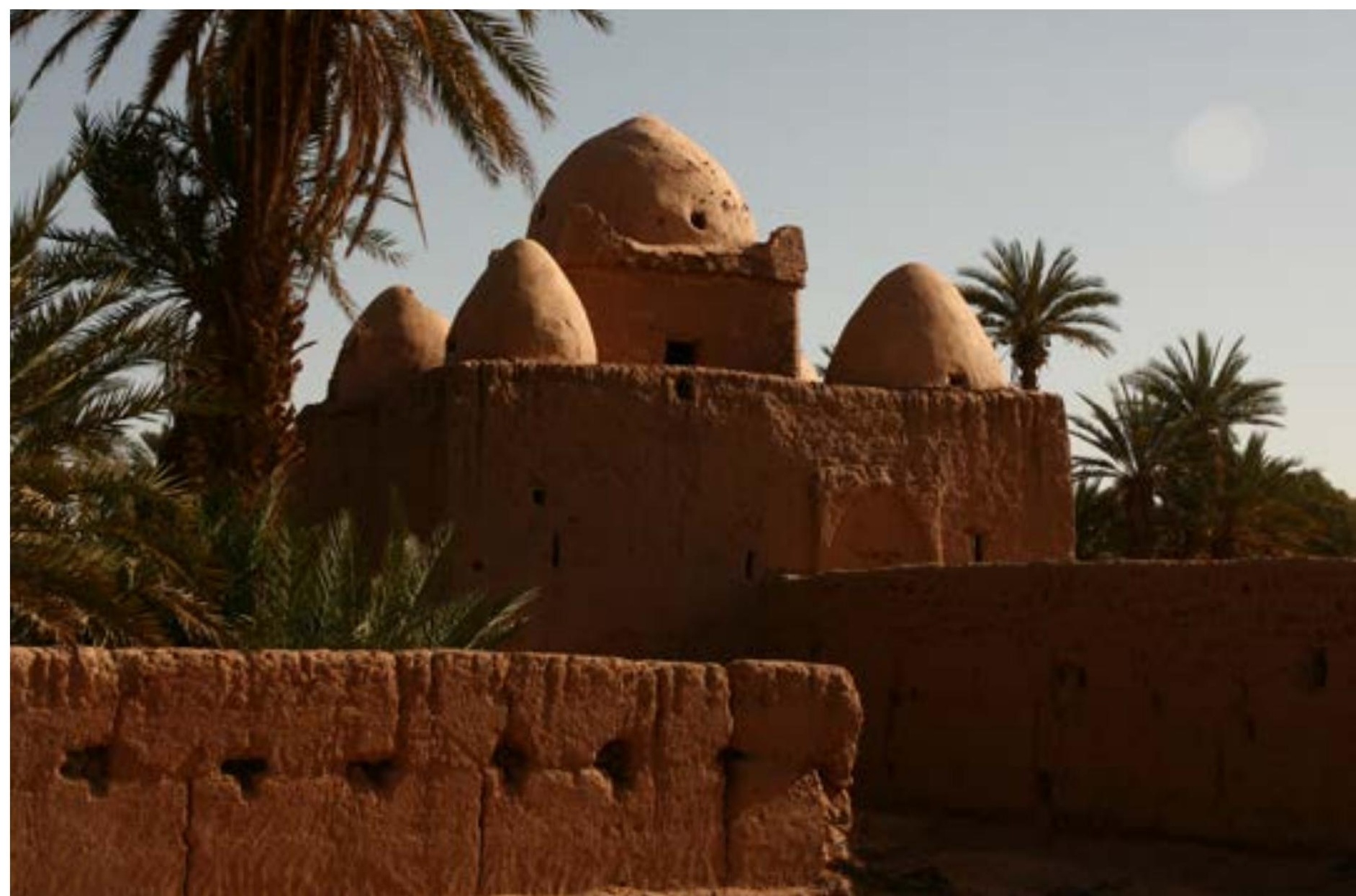



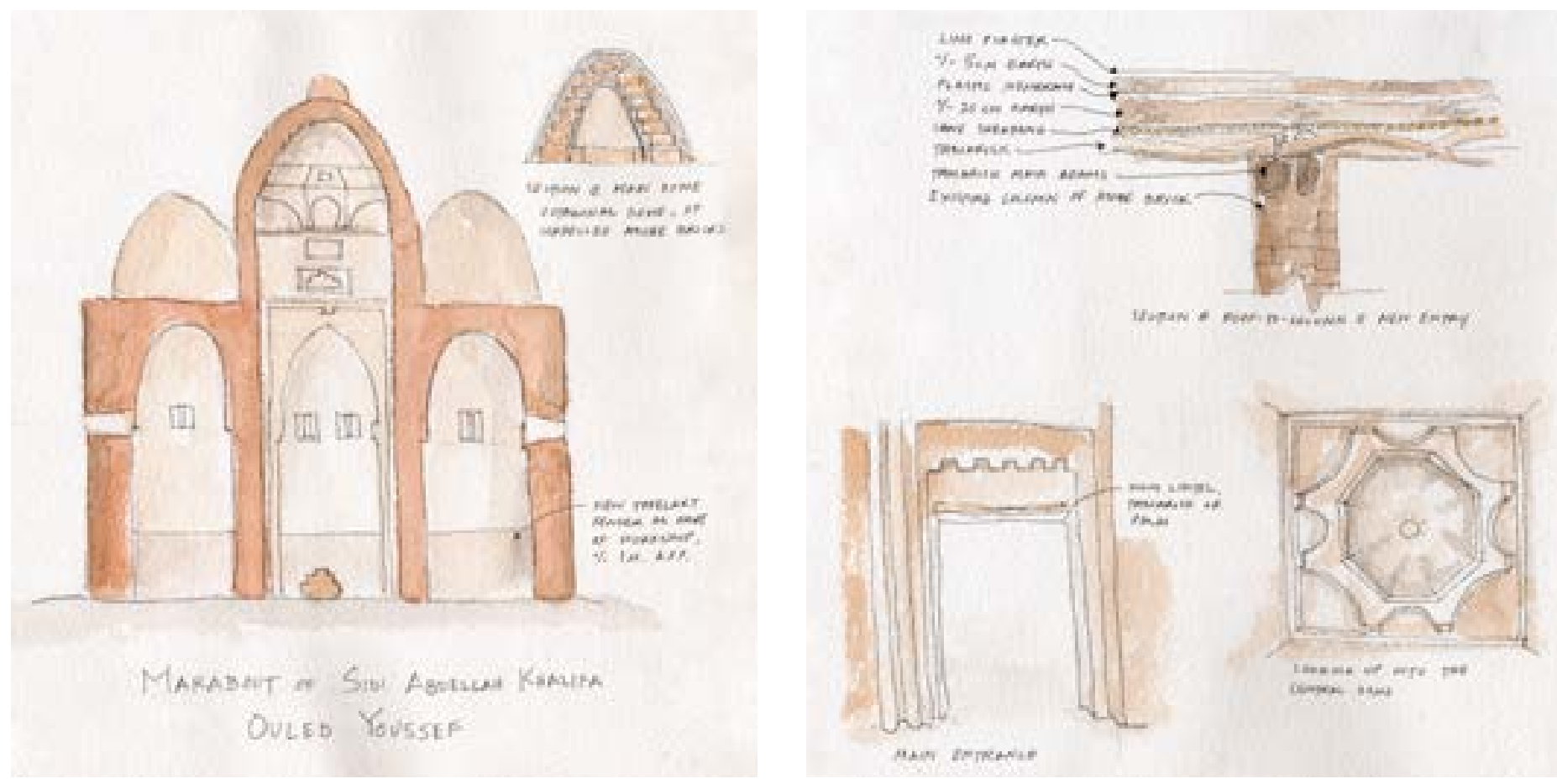

The simplicity and delicacy of the shrine's forms reflect the know-how of the masters who built it over a century ago. The mud, wood and lime covering the domes were skillfully molded so as to create one of the oasis's finest architectures. Its five stepped paraboloids gleam amid the green of the palm groves and constitute a landmark overlooking the countryside by the turreted walls of the two neighboring ksur.

The interior is a space in twilight, with some light slanting in through deep, narrow, splayed slits in the facades, just $10-12 \mathrm{~cm}$ wide on the outside and $38-40 \mathrm{~cm}$ high, and more light coming in through the wider and shallower openings in the drum of the central dome so that the inner lighting is focused with sharp contrast over the tomb that is the shrine's reason for being. The plentiful suspended dust gives materiality to the beams and heightens their symbolic force as they slant down from the central dome.
La sencillez y la delicadeza de sus formas reflejan el saber hacer de los maestros que lo construyeron hace ya más de un siglo. El barro, la madera y la cal que protege sus cúpulas fueron magistralmente moldeados para crear una de las más bellas arquitecturas del oasis. Sus cinco paraboloides escalonados refulgen en mitad del verde de las palmeras y se convierten en un hito que domina el paisaje situado frente a las murallas torreadas de los dos ksur vecinos.

Respecto al interior, es un espacio en penumbra, donde solo entra la luz a través de los profundos, estrechos y abocinados huecos de sus fachadas, de solo unos 10 o 12 centímetros de ancho en su alzado exterior y entre 38 y 40 centímetros de altura; $y$, principalmente, de los más amplios y menos profundos huecos abiertos en el tambor de su cúpula central, que hacen que la iluminación interior se concentre con un fuerte contraste sobre la tumba que da sentido a la construcción. El abundante polvo en suspensión aporta materialidad e incrementa el poder simbólico de los rayos de luz que atraviesan el espacio desde la cúpula central.
A simplicidade e a delicadeza das suas formas refletem o saber-fazer dos mestres que o construíram há já mais de um século. O barro, a madeira e a cal que protege as suas cúpulas foram magistralmente moldados para criar uma das mais belas arquiteturas do oásis. Os seus cinco paraboloides escalonados refulgem na metade do verde das palmeiras, convertendo-se numa referência que domina a paisagem situada em frente às muralhas torreadas dos dois ksur vizinhos.

Relativamente ao interior, é um espaço penumbroso, onde mal entra a luz através dos profundos, estreitos e afunilados vãos das suas fachadas, de apenas uns 10 ou 12 centímetros de largura no seu alçado exterior e entre 38 e 40 centímetros de altura; e, principalmente, dos mais amplos e menos profundos vãos abertos no tambor da sua cúpula central, que fazem que a iluminação interior se concentre com um forte contraste sobre a tumba que dá sentido à construção. A abundante poeira em suspensão proporciona materialidade e incrementa o poder simbólico dos raios de luz que atravessam o espaço desde a cúpula central. 


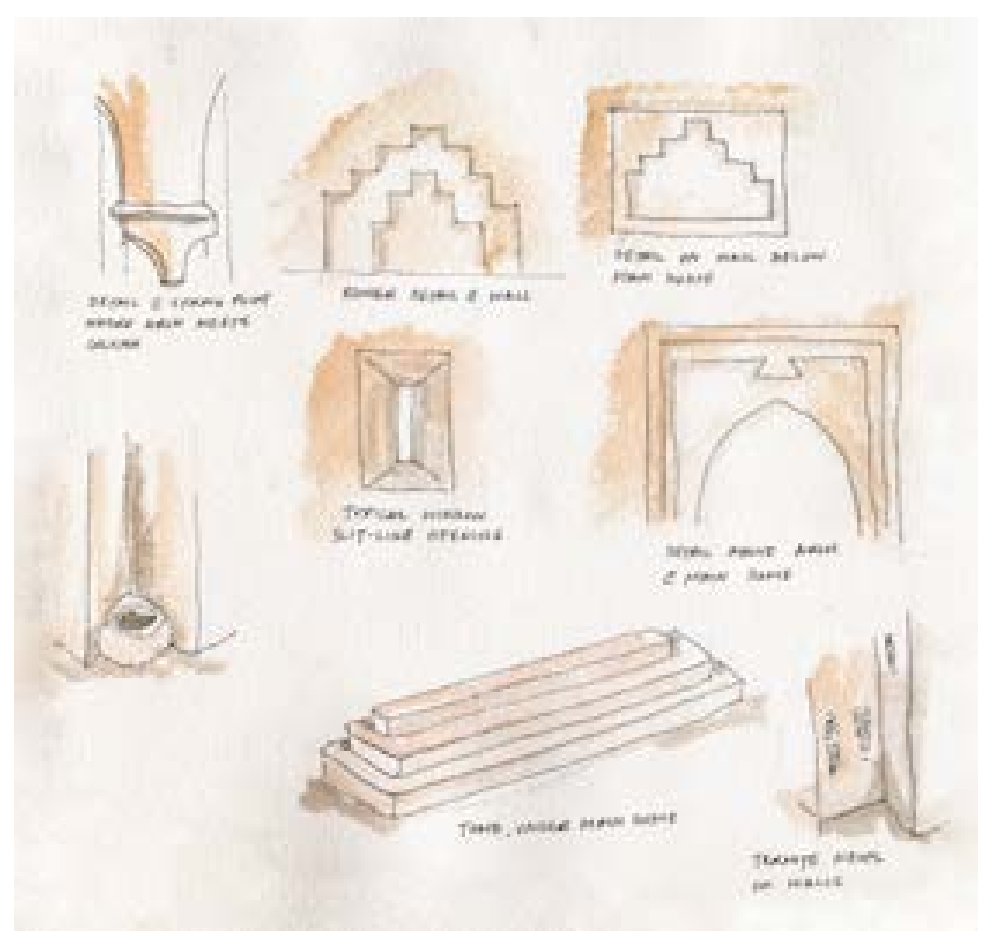

The tomb itself stands directly on the rammed-earth floor and stretches 3.33 $\mathrm{m}$ long and $30 \mathrm{~cm}$ high with double adobe stepping, coated on the outside at some point with cement mortar.

The anteroom is a low shady chamber opening to the south and annexed to the main entrance subsequent to the building of the original shrine, as its roof cuts across the portal composition. It contains a lengthwise row of pillars forming two bays. To the west, adjoining both this chamber and the main building, there is a cemetery, while the well, today a water tank, was located to the east.

The entrance to the marabout is also low, just $1.40 \mathrm{~m}$ high and $87 \mathrm{~cm}$ wide. But it is framed and highlighted by an elaborate composition with side pilasters and serrated decoration over the lintel, above which is a blind parabolic arch, subtly multifoil in form and contained in an alfiz frame. When the restoration work began, the flat roof of the annexed chamber intersected the portal at the level of the lintel, preventing those entering from appreciating the elaborate upper part.
La tumba propiamente dicha se levanta directamente sobre el pavimento de tierra apisonada y es un elemento longitudinal de 3,33 metros de longitud y 30 centímetros de altura con un doble escalonamiento realizado con adobes y fue revestido exteriormente en algún momento con mortero de cemento.

La mencionada antesala es un espacio bajo y sombreado que se abre hacia el sury fue adosada a la puerta principal en algún momento posterior a la construcción del edificio original, ya que su forjado secciona la composición de esta portada. Cuenta con una hilera longitudinal central de pilares que la dividen en dos crujías. Hacia el oeste, adosado tanto a este espacio como al principal, se sitúa un cementerio, mientras que el pozo, hoy un depósito de agua, estaba situado hacia el este.

La puerta de acceso al morabito es también baja. Tiene apenas 1,40 metros de altura y 87 centímetros de ancho. Pero está enmarcada y realzada por una cuidada composición con pilastras laterales y decoración dentada sobre el dintel, sobre los que se alza un arco parabólico ciego, sutilmente polilobulado y enmarcado
Diverse constructive details of the Marabout Diversos detalles constructivos del Morabito Diversos pormenores construtivos do Marabu (Amanda Roelle)
A tumba propriamente dita levanta-se diretamente sobre o pavimento de terra batida e é um elemento longitudinal de 3,33 metros de comprimento e 30 centímetros de altura com um duplo escalonamento realizado com adobes, tendo sido revestido exteriormente nalgum momento com argamassa de cimento.

A mencionada antecâmara é um espaço baixo e sombrio que se abre para o sul e foi adossada à porta principal nalgum momento posterior ao da construção do edifício original, já que a sua estrutura secciona a composição desta portada. Conta com uma fila longitudinal central de pilares que a divide em duas galerias. Orientado a oeste, adossado tanto a este espaço como ao principal, encontra-se um cemitério, enquanto que o poço, hoje depósito de água, estava orientado a este.

A porta de acesso ao marabu é também baixa. Tem apenas 1,40 metros de altura e 87 centímetros de largura. Mas está enquadrada e realçada por uma composição com pilastras laterais e por uma decoração dentada sobre o dintel, sobre os que se alça um arco parabólico cego, subtilmente polilobulado e 
In the ambulatory, light false parabolic adobe arches no more than $15 \mathrm{~cm}$ thick link the abutments to the perimeter walls. The four abutments are also interlinked by another four false parabolic adobe arches with a greater thickness, some $25-30 \mathrm{~cm}$. These four arches are braced at impost level with tamarisk beams, though some of these braces have been lost. They have an alfiz frame decorated with various local motifs at the top, both centrally and at the corners, and these four arches bear the square-based drum, $1.60 \mathrm{~m}$ high, on which stands the central dome.

The domes, simple and irregular in shape and with inner diameters of 1.25$1.35 \mathrm{~m}$, stand on an octagonal timber substructure and were built of corbeled courses of adobe. So in building terms they are false domes, and their pointed shape results from the need to facilitate the laying of adobe bricks without
En el deambulatorio, ligeros falsos arcos parabólicos de adobe de no más de 15 centímetros de sección conectan los machones con los muros perimetrales. Los cuatro machones están además unidos entre sí por otros cuatro falsos arcos parabólicos de adobe con mayor sección, unos 25 o 30 centímetros. Estos cuatro arcos están atirantados a la altura de las impostas con vigas de tamarisco, aunque estos tirantes se han perdido en algunos de ellos. Cuentan con un alfiz decorado con diversos motivos locales en su extremo superior, tanto en su centro como en sus esquinas, y son estos cuatro arcos los que soportan el tambor de base cuadrada y 1,60 metros de altura sobre el que se alza la cúpula central.

Las cúpulas, de trazado sencillo e irregular y con un diámetro interior de 1,25 a 1,35 metros, se alzan sobre una subestructura ochavada de madera y están ejecutadas por aproximación de hiladas de adobe.
No deambulatório, ligeiros arcos falsos parabólicos de adobe de não mais de 15 centímetros de secção conectam os pilares com as paredes perimetrais. Os quatro pilares estão também unidos entre si por outros quatro arcos falsos parabólicos de adobe de maior secção, uns 25 ou 30 centímetros. Estes quatro arcos estão atirantados à altura das impostas com vigas de tamarisco, ainda que estas tirantes se tivessem perdido nalgum deles. Contam com um alfiz decorado com diversos motivos locais no seu extremo superior, tanto no seu centro como nas suas esquinas, e são estes quatro arcos os que suportam o tambor de base quadrada e o 1,60 metro de altura sobre o que se alça a cúpula central.

As cúpulas, de traçado simples e irregular e com um diâmetro interno entre 1,25 e 1,35 metros, alçam-se sobre uma subestrutura octogonal de madeira e estão executadas por aproximação de fiadas

1: Interior of the Marabout of Sidi Abdellah Khalifa with his tomb 2: Bottom-up interior view of the Marabout's central dome | 1: Interior of the Marabout of Sidi Abdellah Khalifa with his tomb 2: Bottom-up interior view of the Marabout's central dome | 1: Interior do Marabu de Sidi Abdellah Khalifa com a sua tumba 2: Vista da cúpula central do marabu desde o seu interior
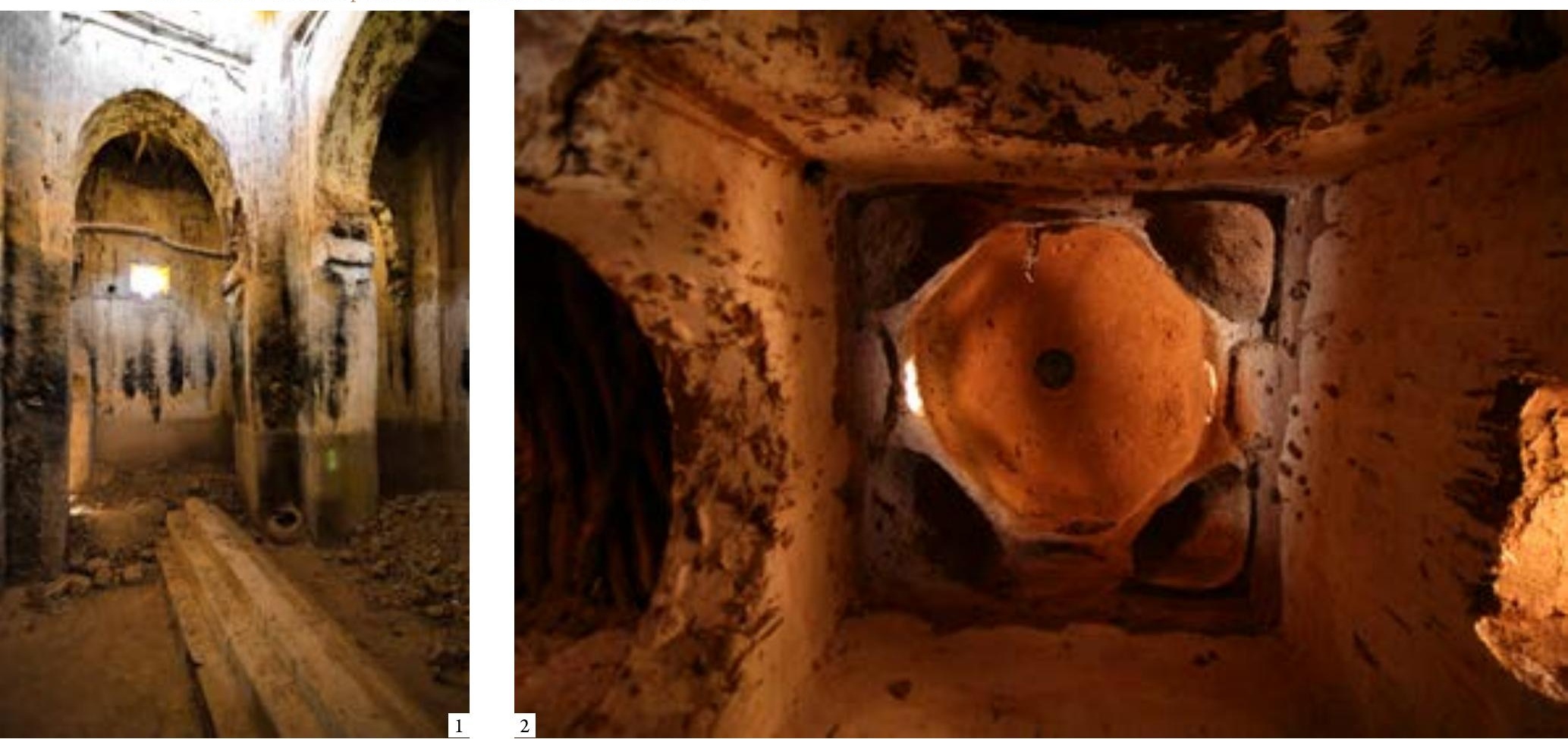
falsework. The domes at the marabout's four corners have a continuous intrados whereas the larger central dome is octagonal inside, and so it maintains its course throughout. Underneath the dome's spring points are false decorative squinches with roughly the shape of half cloister vaults.

The main shrine's four sections of flat roof and the anteroom roof are made of palm-wood beams or tamarisk branches, sinuous and irregular and highly resistant to the ubiquitous termites, which barely get beyond their outer rings. This is not so with palm wood, much more susceptible to insect attack. Of whatever material, all the flat roofs have a compression layer of rammed earth over palm-frond bedding. The lack of maintenance and
Constructivamente son, por tanto, falsas cúpulas, y su forma apuntada responde a la necesidad de facilitar la colocación de los ladrillos de adobe en ausencia de cimbras. Las cúpulas de las cuatro esquinas del morabito tienen el intradós continuo, mientras que la cúpula central, de mayor tamaño, hacia el interior es ochavada, con lo que mantiene el trazado del arranque en todo su desarrollo. Bajo el arranque de las cúpulas penden unas falsas trompas decorativas trazadas aproximadamente en forma de media bóveda de rincón de claustro.

Los cuatro tramos de cubierta plana del edificio principal y la cubierta de la antesala están ejecutados con vigas de palmera o con ramas de tamarisco, sinuosas e irregulares, pero muy resistentes a las omnipresentes termitas, de adobe. Construtivamente são, portanto, falsas cúpulas, e a sua forma apontada responde à necessidade de facilitar a colocação dos tijolos de adobe ante a ausência de cimbres. As cúpulas das quatro esquinas do marabu têm o intradorso contínuo, enquanto que a cúpula central, de maior tamanho, orientada para o interior é octogonal, com o que mantém o traçado do arranque em todo o seu desenvolvimento. Por debaixo do arranque das cúpulas pendem umas falsas trompas decorativas traçadas aproximadamente em forma de meia abóbada de claustro.

Os quatros lanços da cobertura plana do edifício principal e da cobertura da antecâmara estão executados com vigas de palmeira ou com ramos de tamarisco, sinuosos e irregulares, mas muito resistentes às omnipresentes térmitas, que rara-

Condition of the exterior of the domes and the roof before restoration | Estado del exterior de las cúpulas y la cubierta antes de la restauración | Estado do exterior das cúpulas e a cobertura antes da restauração
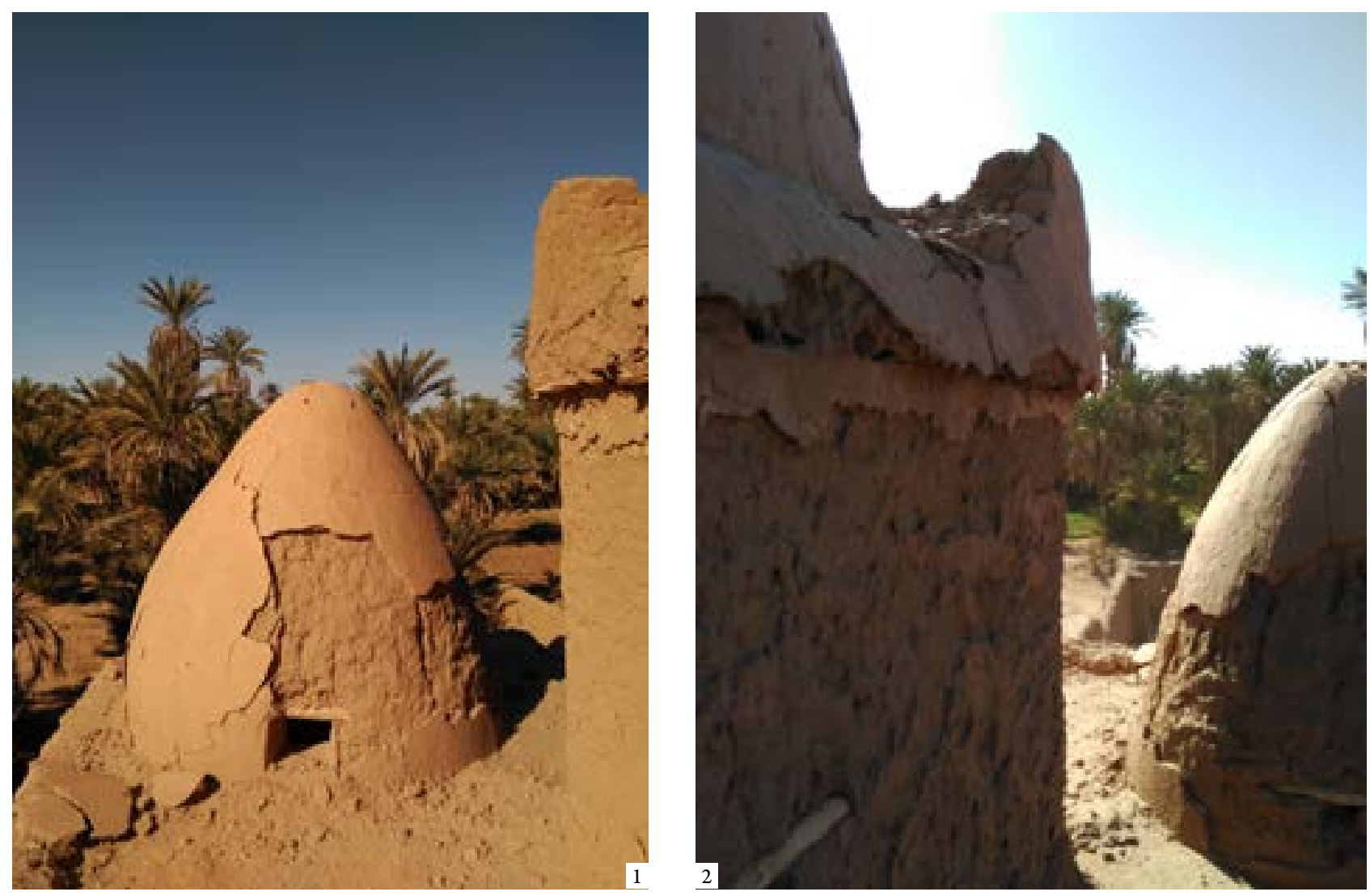
consequent poor rainwater drainage had caused deterioration in all the horizontal structures, and most were damaged or partially collapsed to a degree beyond recovery.

All the walls are rendered with mud and straw mortars, washed over with lime on interior elevations. The existerior mud mortars had been eroded and were all but missing in some places owing to the shrine's disrepair. The interior renders, sculpted in successive layers of decorative stepped motifs, are blackened in many places by soot from candles placed inside the shrine. The roof damage had also resulted in many stains and losses of material owing to water leakage. Outside, only the portal and domes were rendered with lime mortar, though in previous repairs of que apenas logran ir más allá de sus anillos exteriores. No ocurre lo mismo con la palmera, mucho más susceptible a estos ataques. Sean del material que sean, todas las cubiertas planas contaban con una torta de compresión realizada con tierra apisonada sobre una cama de hoja de palmera. La falta de mantenimiento y las consiguientes dificultades para evacuar el agua de lluvia habían deteriorado todas las estructuras horizontales $y$ en su mayor parte presentaban tantos daños y derrumbes parciales que eran ya irrecuperables.

Todos los muros están revestidos con morteros de barro y paja, sobre los que existe una jabelga de cal en los alzados interiores. Los morteros de barro exteriores estaban muy lavados e incluso prácticamente desaparecidos en algunos mente conseguem ir mais além dos seus anéis exteriores. $\mathrm{O}$ mesmo não acontece com a palmeira, muito mais suscetível a estes ataques. Qualquer que seja o material, todas as coberturas planas contavam com uma torta de compressão realizada com terra batida sobre um leito de folha de palmeira. A falta de manutenção e as conseguintes dificuldades para evacuar a água da chuva tinham deteriorado todas as estruturas horizontais e na sua maior parte apresentavam tantos danos e desabamentos parciais que eram já irrecuperáveis.

Todas as paredes estão revestidas com argamassa de barro e palha, sobre as que existe uma camada de cal nos alçados interiores. A argamassa de barro exterior estava bastante desgastada e inclusive quase desaparecida nalguns

Bottom-up interior view of the central dome and the floors | Vista interior de la cúpula central y un forjado | Vista interior da cúpula central e uma estrutura de madeira

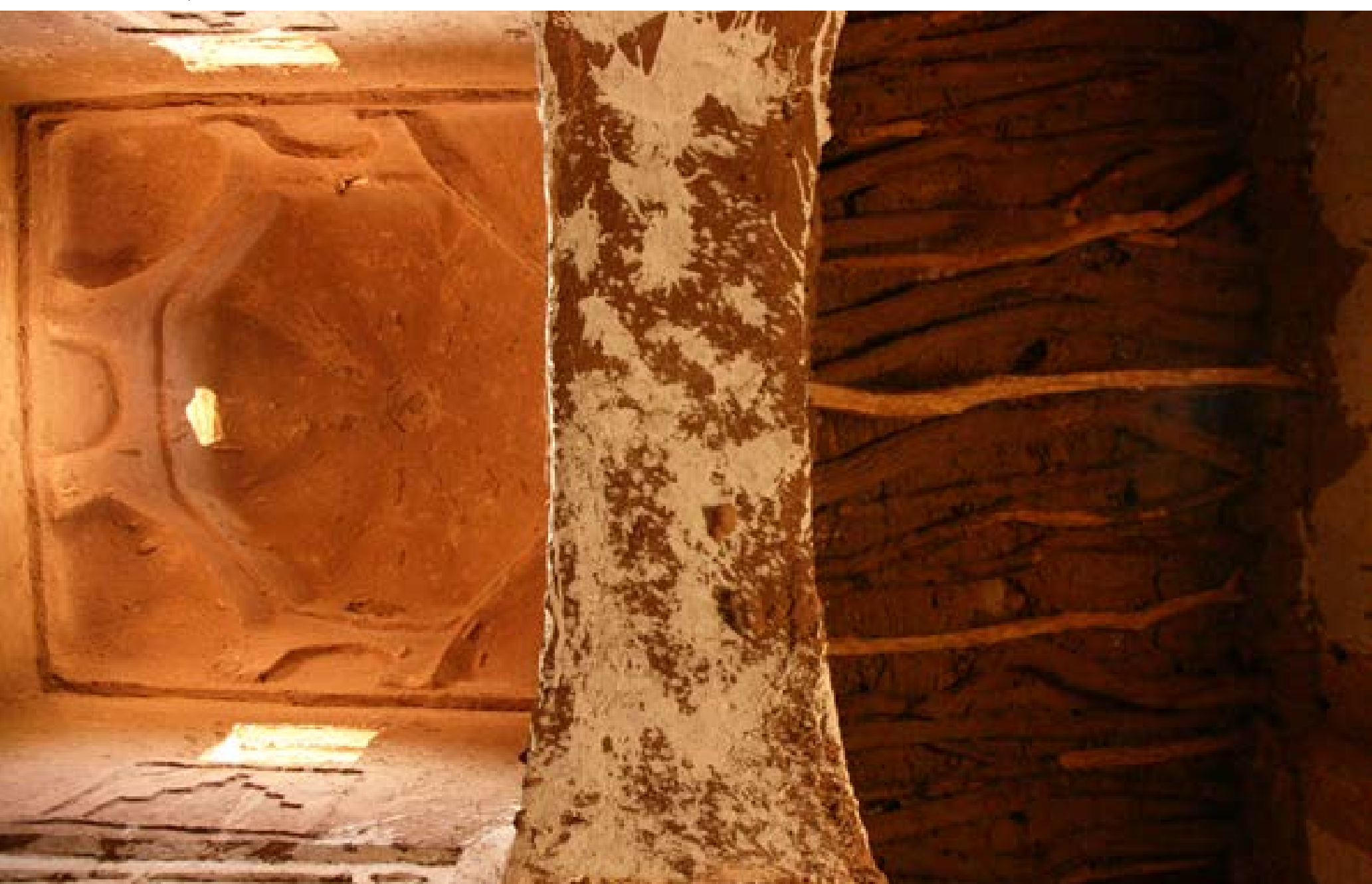


the domes this render had been coated with a mixed mortar of mud, cement and lime with barely any adherence to the previous layers. The voids generated by this ill-advised measure had helped the scarce rainfall to significantly damage not just the domes' render but also their adobe structure, in which there were already many cavities. tramos por la falta de mantenimiento del edificio. Los revestimientos interiores, retallados en capas sucesivas con motivos decorativos escalonados, están oscurecidos en numerosos puntos por el hollín procedente de las velas que se colocan en el interior del edificio. El deterioro de las cubiertas había provocado además múltiples manchas y pérdidas de material causadas por las filtraciones de agua. Al exterior, sólo la portada y las cúpulas estaban revestidas con mortero de cal, si bien en alguna reparación anterior de las cúpulas este revestimiento había sido recubierto por un mortero bastardo de barro, cemento y cal sin apenas adherencia con las capas preexistentes. Las oquedades generadas por esta inapropiada solución habían contribuido a que las escasas precipitaciones existentes dañaran significativamente no sólo los revestimientos de las cúpulas, sino también su estructura de adobe, en la que existían ya diversas lagunas.

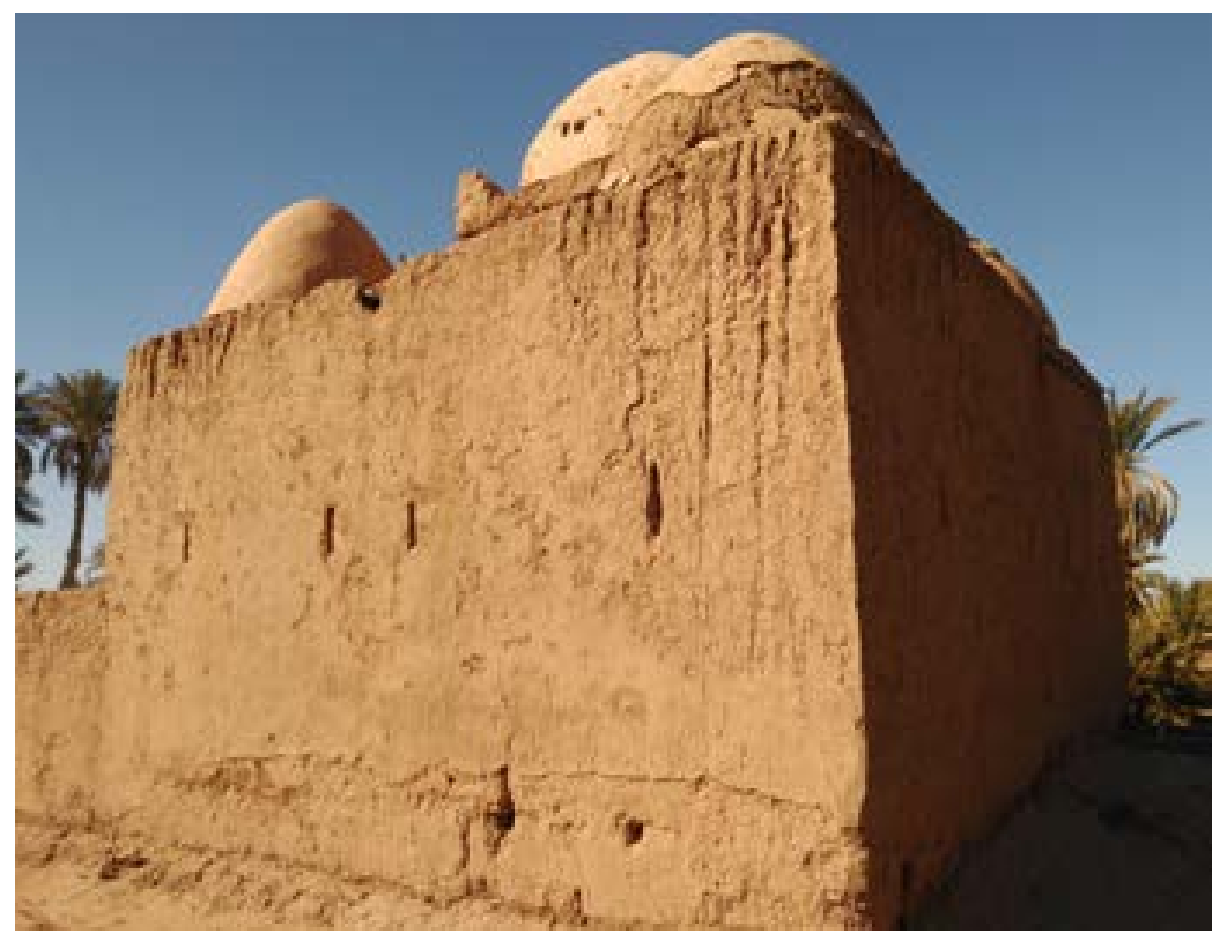

lanços devido à falta de manutenção do edifício. Os revestimentos interiores, retalhados em camadas sucessivas com motivos decorativos escalonados, estão escurecidos em numerosos pontos devido à fuligem proveniente das velas que se colocam no interior do edifício. A deterioração das coberturas também provocou múltiplas manchas e perdas de material causadas pelas infiltrações de água. No exterior, apenas a portada e as cúpulas estavam revestidas com argamassa de cal, embora nalguma reparação anterior das cúpulas este revestimento tivesse sido revestido com uma argamassa bastarda de barro, cimento e cal sem qualquer aderência com as camadas pré-existentes. As cavidades provocadas por esta solução inapropriada contribuíram para que as escassas precipitações existentes danificassem consideravelmente não só os revestimentos das cúpulas, mas também a sua estrutura de adobe, na que existiam já algumas lacunas.
Northeast corner of the Marabout. Condition of the exterior finishings prior to the restoration | Esquina noreste del Morabito. Daños en acabados exteriores previos a la intervención | Esquina noroeste do marabu. Danos nas fachadas exteriores antes da intervenção 


\section{Restoration of the marabout}

Terrachidia has since 2012 been engaged in studying, transmitting and promoting traditional building techniques. On undertaking the restoration of traditional architectures, the use where possible of the same materials and techniques with which they were built as well as forms similar or comparable to the existing ones ensures that new additions are compatible with what is already there and avoids significant alterations of composition, structure and function. For this principle to be applied, the professional practice and teachings of local master builders are indispensable. For work such as that done by Terrachidia at the M'hamid Oasis there remain good master builders versed in techniques with rammed earth and adobe, mud and straw renders and the horizontal structures used in floors and roofs, with beams of palm wood (quarter-logs or on rare occasions half-logs, depending on the span to be covered) or tamarisk (available in the form of thick beams and also of branches with short spans and very small cross-sections).

But the fragility of palm wood and the growing scarcity of tamarisk, except where only thin sticks are wanted, mean that reused wood is preferred where possible. Otherwise eucalyptus beams, always available at the local market, need to be bought. And both the production of lime and its use in higher-quality renders, though both were visibly common in the recent past, have now ceased. So the lime and the master builders specialized in working with it now come from other areas farther up the Draa valley.
La restauración del morabito

Terrachidia trabaja desde 2012 en el estudio, la transmisión y la puesta en valor de las técnicas tradicionales de construcción. $\mathrm{Al}$ acometer la restauración de arquitecturas tradicionales, recurrir en la medida de lo posible a los mismos materiales y técnicas de construcción con las que fueron levantadas y a formas análogas o similares a las precedentes asegura la compatibilidad de los nuevos añadidos con las preexistencias y se evitan alteraciones significativas de su composición, su estructura y su funcionamiento. Para poder poner en práctica este principio, la labor profesional y las enseñanzas de los maestros de construcción locales son imprescindibles. En el caso de las obras acometidas por Terrachidia en el oasis de Mhamid, quedan aún buenos maestros de construcción que dominan las técnicas de la construcción con tapial $\mathrm{y}$ adobe, los revestimientos de barro y paja y las estructuras horizontales que se utilizan en forjados y cubiertas, con viguería de palmera (cuartos o en raras ocasiones medios troncos, según la luz a salvar) o de tamarisco (disponible tanto en forma de vigas de gran sección como de ramas de escasa luz y muy reducida sección).

Sin embargo, la fragilidad de la madera de palmera y la creciente escasez de la de tamarisco, salvo en los casos que sólo requieren ramas de pequeña sección, hacen que se opte siempre que sea posible por madera reutilizada, o que sea necesario adquirir vigas de eucalipto, también disponibles hoy en el mercado local. Tanto la producción de cal como su uso para la realización de acabados de especial calidad, si bien es patente que fueron comunes en un pasado reciente, han desaparecido en la actualidad. Por ello, tanto la cal como los maestros especializados en trabajarla proceden hoy de otras zonas del valle del Draa situadas aguas arriba.
A restauração do marabu

Terrachidia trabalha desde 2012 no estudo, transmissão e valorização das técnicas tradicionais de construção. Ao empreender a restauração de arquiteturas tradicionais, recorrer dentro do possível dos mesmos materiais e técnicas de construção com as que foram levantadas e a formas análogas ou semelhantes aos precedentes garante a compatibilidade das novas adições com as pré-existentes e evitam-se alterações significativas na sua composição, estrutura e funcionamento. Para poder pôr em prática este princípio, o labor profissional e a transmissão de conhecimento dos mestres de construção locais são imprescindíveis. No caso das obras efetuadas por Terrachidia no oásis de Mhamid, ainda há mestres de construção bons que dominam as técnicas da construção com taipal e adobe, os revestimentos de barro e palha e as estruturas horizontais que se utilizam em tetos e coberturas, com vigas de palmeira (quartos ou em raras ocasiões meios troncos, segundo a luz a salvar) ou de tamarisco (disponível tanto em forma de vigas de grande secção como de ramos de escassa luz e muito reduzida secção).

No entanto, a fragilidade da madeira de palmeira e a crescente escassez da madeira de tamarisco, exceto nos casos que apenas requerem ramos de pequena secção, fazem que se opte sempre que seja possível por madeira reutilizada, ou que seja necessário adquirir vigas de eucalipto, também disponíveis hoje em dia no mercado local. Tanto a produção de cal como o seu uso para a realização de acabamentos de qualidade especial, ainda que patente que foram comuns num passado recente, estas práticas desapareceram no presente. Por isso, tanto a cal como os mestres especializados na sua elaboração provêm hoje de zonas do vale do Draa situadas águas acima. 


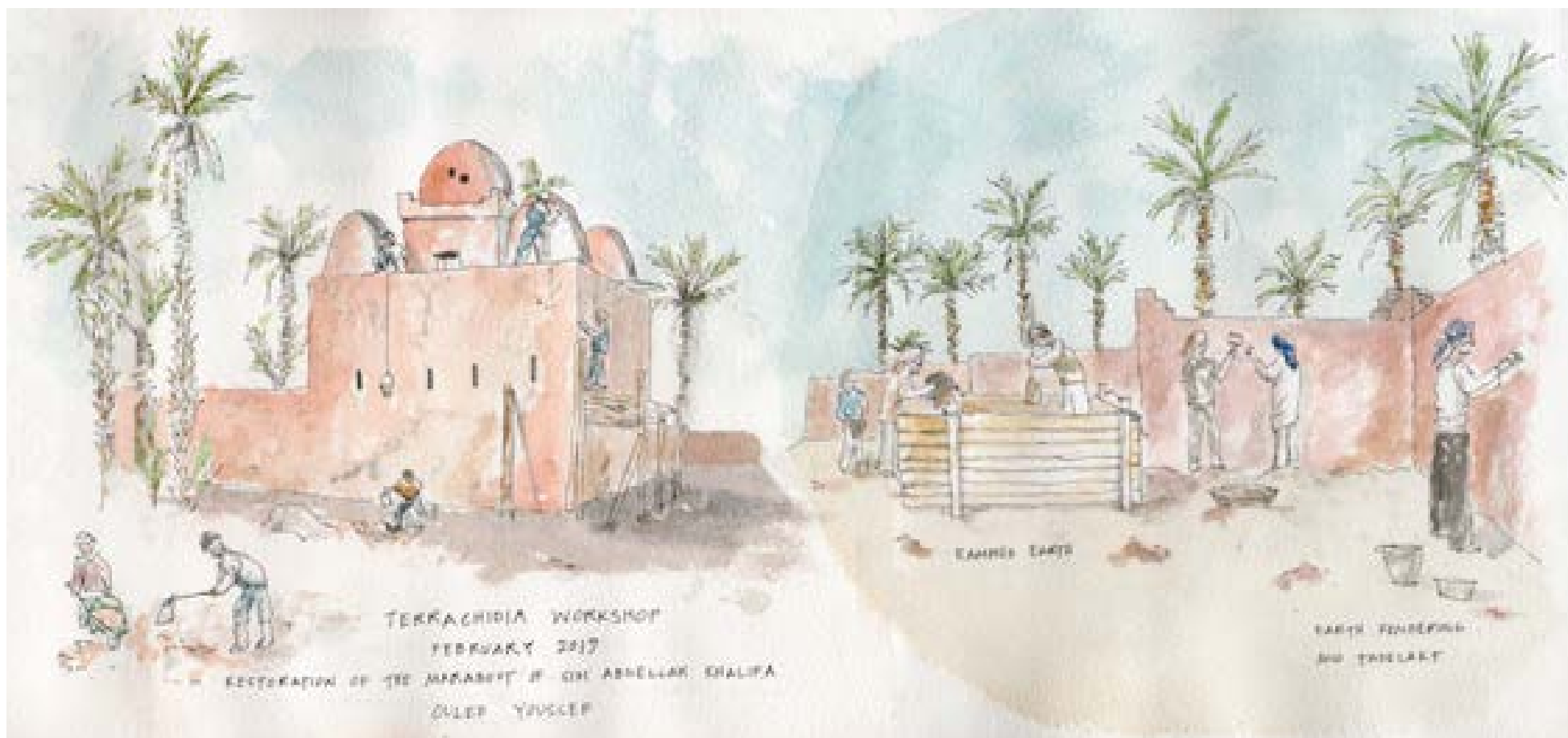

Sketch on the restoration works of the Marabout | Dibujo de los trabajos de restauración del Morabito | Desenho dos trabalhos de restauração do Marabu (Amanda Roelle)

In the case of the restoration of the marabout of Sidi Abdullah Khalifa, the process began with the shrine being documented so as to elucidate how it was built and the defects it had acquired and thus to be able to assess the extent of work required. This documentation was performed on various trips made by Terrachidia in 2014-15, and in September 2018 the dataset was assessed with a view to defining the steps to be taken: after agreeing the details of the work with the municipality of M'hamid and the Ouled Youssef community leaders (suitable local masters and apprentices for each task involved along with matters of materials and their transportation, tools, stockpiles and general site organization), the restoration work was carried out over two stages in February and October 2019.

In all the work, apart from the Terrachidia and ArCHIAM teams, there were 38 participants from several countries; the maalem (master builder) Abdelkader Mahassine, a specialist in lime renders such as tadelakt and a regular Terrachidia partner for such
En el caso de la restauración del morabito de Sidi Abdullah Khalifa, el proceso comenzó por la documentación inicial del edificio para conocer mejor su constitución y el cuadro patológico que presentaba y poder así evaluar el alcance de la intervención que requería. Estos trabajos de documentación se llevaron a cabo durante los diferentes viajes realizados por Terrachidia entre 2014 y 2015 y se evaluaron más adelante estos datos para definir las actuaciones a realizar en septiembre de 2018: Tras acordar los detalles de la obra con la Commune de Mhamid y la cabila de Ouled Youssef (maestros y aprendices locales apropiados para cada trabajo a realizar, así como cuestiones relativas a los materiales y su transporte, las herramientas, las zonas de acopio y la organización de la obra en general), los trabajos de restauración se ejecutaron en dos etapas durante los meses de febrero y octubre de 2019.

En el conjunto de los trabajos, además de los equipos de Terrachidia y ArCHIAM, intervinieron 38 participantes llegados desde numerosos países; el maalem (maestro) Abdelkader Mahassine, especialista en revestimientos de cal
No caso da restauração do marabu de Sidi Abdullah Khalifa, o processo começou pela documentação inicial do edifício para conhecer melhor a sua constituição e o quadro patológico que apresentava para assim poder a avaliar o alcance da intervenção que requereria. Estes trabalhos de documentação realizaramse durante as diferentes viagens realizadas por Terrachidia, entre 2014 e 2015 , e os dados foram avaliados posteriormente para definir as ações a realizar em setembro de 2018: após o acordo dos pormenores da obra com a Commune de Mhamid e a cabila de Ouled Youssef (mestres e aprendizes locais idóneos para cada trabalho a realizar, bem como questões relativas aos materiais e ao seu transporte, as ferramentas, as zonas de recolha e a organização da obra em geral), os trabalhos de restauração foram executados em duas fases durante os meses de fevereiro e outubro de 2019.

No conjunto dos trabalhos, para além das equipas de Terrachidia e ArCHIAM, intervieram 38 participantes provenientes de vários países; o maalem (mestre) Abdelkader Mahassine, especialista em revestimentos de cal como o tadelakt e colaborador habitual de Terrachidia para 
finishes; the local master builders Bouchaib Bourhim, Abdelkader Ahssane, Brahim Banhman, Lahsan Kuidr, Hosine Karoumi and Saaid Gahmini; and ten young apprentices from Ouled Youssef itself.

The adobe bricks needed were supplied by Ouled Youssef families, to whom the bricks made during the project, not cured enough for use in building, were given in return. Tamarisk wood was needed only in the form of thin branches and so was easy to source. For the layers of compression bedding in the roofs we opted to buy rolls of cane rather than using palm fronds, as today this is the commonest traditional solution for its ease of application. Water could simply be drawn from the nearby tank and earth was taken from near the shrine. The municipality of M'hamid helped with transporting some of the sand and straw needed. como el tadelakt y colaborador habitual de Terrachidia para este tipo de acabados; los maestros de obra locales Bouchaib Bourhim, Abdelkader Ahssane, Brahim Banhman, Lahsan Kuidr, Hosine Karoumi y Saaid Gahmini; y diez aprendices jóvenes del propio Ouled Youssef.

Los ladrillos de adobe necesarios fueron cedidos por familias de Ouled Youssef, a quienes se les devolvieron a cambio los producidos durante la obra, aún no suficientemente curados para haber sido usados en ella. Sólo se necesitaba madera de tamarisco en forma de ramas de pequeña sección y fue por tanto fácil de conseguir. Para el asiento de las capas de compresión del forjado se optó por adquirir rollos de cañizo en lugar de utilizar hojas de palmera, al ser la solución tradicional más común en la actualidad por su rápida colocación. El agua pudo sencillamente obtenerse del este tipo de acabamentos; os mestres de obra locais Bouchaib Bourhim, Abdelkader Ahssane, Brahim Banhman, Lahsan Kuidr, Hosine Karoumi e Saaid Gahmini; e dez aprendizes jovens do próprio Ouled Youssef.

Os tijolos de adobe necessários foram cedidos por famílias de Ouled Youssef, a quem em troca se lhes devolveu os produzidos durante a obra, ainda não curados o suficientemente para que pudessem ter sido usados na mesma. Apenas se precisava de madeira de tamarisco em forma de ramos de pequena secção, pelo que foi fácil de conseguir. Para o assentamento das camadas de compressão da estrutura de horizontal de madeira optou-se por adquirir rolos de caniço em vez de usar folhas de palmeira, como era a solução tradicional mais comum atualmente devido à sua rápida colocação. A água pôde ser simplesmente obtida do

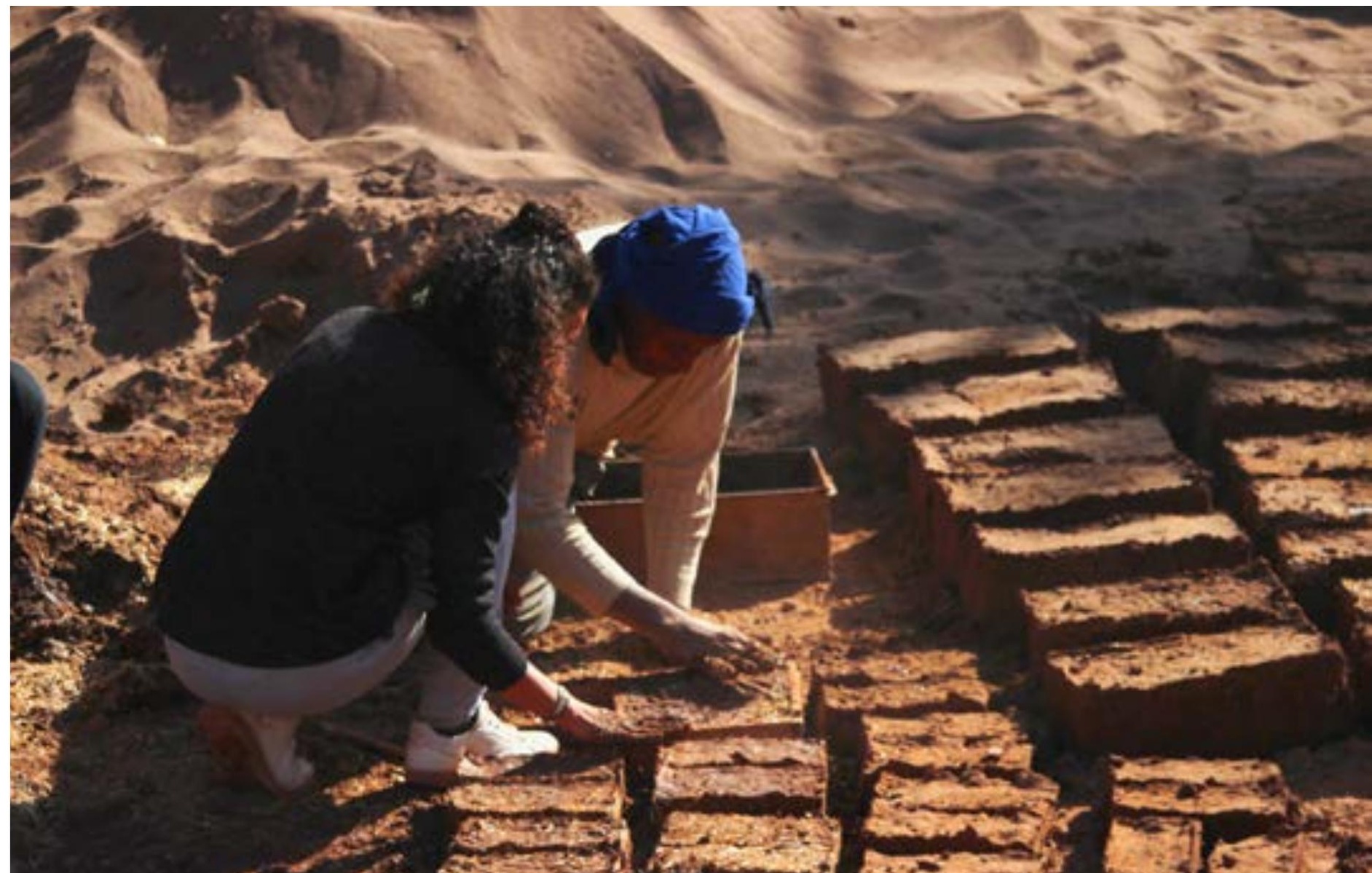


The first tasks undertaken were intended to allow us to work safely at the various levels of the building in later phases of work. For the same reason we worked in stages: the levels were secured from bottom up, so that once consolidated, each one gave safe and easy access to the next one.

Thus we first demolished and rebuilt the roof of the south-facing anteroom - the lower-level roof from which there would be easy access to the roof of the main volume. This was the shrine's least well preserved roof, despite being a later addition, as it was relatively poorly built. Its deterioration was such that a partial replacement would have been an insufficient remedy, so it had to be replaced in full: two complete lengthwise bays with thin tamarisk ceiling joists on which cane bedding depósito cercano y la tierra, del propio entorno del edificio. La Commune de Mhamid colaboró en el transporte de parte de la arena y la paja requeridos.

Los primeros trabajos que se acometieron estuvieron dirigidos a que se pudiera trabajar con seguridad en los distintos niveles del edificio durante las fases posteriores de la obra. Se procedió por el mismo motivo de forma escalonada: se aseguraron las distintas alturas de abajo hacia arriba, de forma que, una vez consolidadas, cada una de ellas permitiera acceder con comodidad y seguridad a la situada inmediatamente por encima.

Se procedió por ello a demoler y reconstruir primero la cubierta de la antesala meridional, la superficie situada a una cota más baja, y desde la que podía accederse con mayor facilidad a la cubierta del cuerpo principal. Se depósito próximo e a terra, do próprio entorno do edifício. A Commune de Mhamid colaborou no transporte de parte da areia e da palha requeridos.

Os primeiros trabalhos que se elaboraram estiveram orientados para que se pudesse trabalhar com segurança nos distintos níveis do edifício durante as fases posteriores da obra. Procedeu-se pelo mesmo motivo de forma escalonada: assegurar as diferentes alturas de baixo para cima, de forma a, uma vez consolidadas, cada uma delas permitisse aceder com comodidade e segurança à situada imediatamente por cima.

Procedeu-se por isso primeiro à demolição e à reconstrução da cobertura da antecâmara meridional, a superfície situada a uma cota mais baixa, e desde a qual se podia aceder mais facilmente à cobertura do corpo principal.

Demolition and reconstruction of the roof of the south-facing anteroom | Demolición y reconstrucción de la cubierta de la antesala meridional| Demolição e reconstrução da cobertura da antecâmara meridional
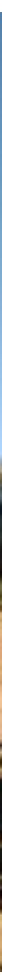
was laid along with a top layer of rammed earth. We opted not to prolong the roofing over the west bay right up to the main shrine so as to prevent the portal composition from being intersected again by this roof, allowing the portal to be viewed as originally on approaching the shrine. The inclusion of a skylight at this point rather than in the middle of the anteroom, where one had been previously, also helped highlight the main entrance. trataba de la cubierta peor conservada del edificio, pese a tratarse de un añadido posterior, por ser más pobre su ejecución. Su deterioro era tal que cualquier sustitución parcial hubiera sido un remedio insuficiente, por lo que hubo que reemplazarla en su totalidad: dos crujías longitudinales completas con viguería de tamarisco de pequeña sección sobre las que se colocó la cama de cañizo y la capa final de tierra compactada. Se optó por no llevar el forjado de una de las dos crujías, la occidental, hasta el cuerpo principal del edificio. Con ello, se evitó que la composición de la portada volviera a quedar seccionada por este forjado y se logró que pudiera apreciarse nuevamente al acceder al edificio. Además, la introducción de un lucernario en este punto en lugar de en el centro de la antesala, sobre el que estaba anteriormente, contribuía a realzar la portada principal.
Tratava-se da cobertura do edifício pior conservada, apesar de se tratar de uma adição posterior, por ser mais pobre a sua execução. A sua deterioração era de tal modo que qualquer substituição parcial teria sido um remédio insuficiente, pelo que este teve de ser substituída na sua totalidade: duas galerias longitudinais completas com vigas de tamarisco de pequena secção sobre as que se colocou o leito de caniço e a camada final de terra compactada. Optou-se por não levar a estrutura de madeira de uma das galerias, a ocidental, até ao corpo principal do edifício. Com isto evitou-se que a composição da portada voltasse a ficar seccionada por esta estrutura de madeira e conseguiu-se que pudesse ser apreciada novamente ao aceder ao edifício. Para além disso, a introdução de uma lucerna neste ponto em vez do centro da antecâmara, sobre o qual estava antes, contribuía a realçar a portada principal.

The roof of the south-facing anteroom before and after its reconstruction | Cubierta de la antesala meridional antes y después de su reconstrucción | Cobertura da antecâmara meridional antes e depois da sua reconstrução
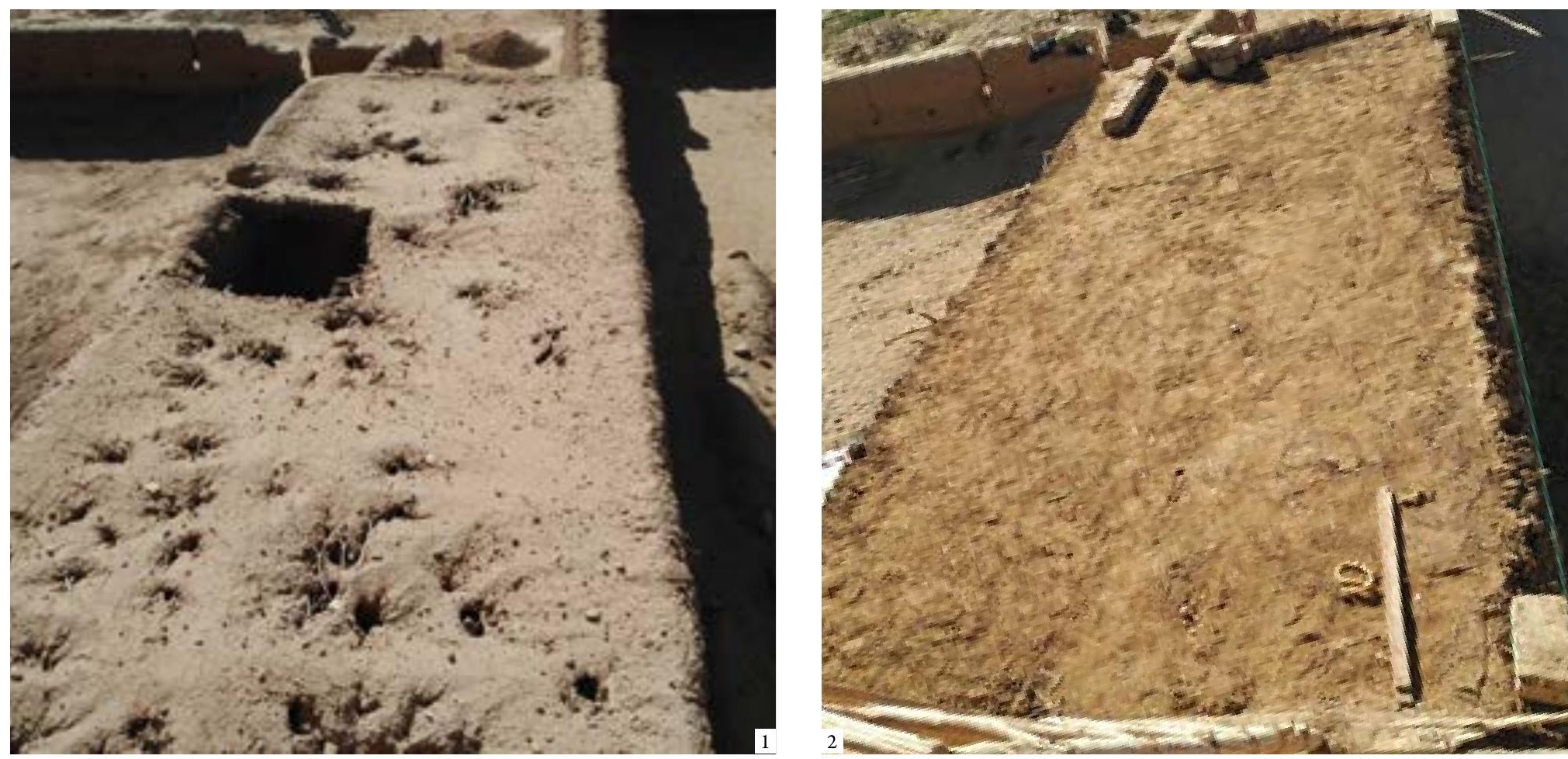

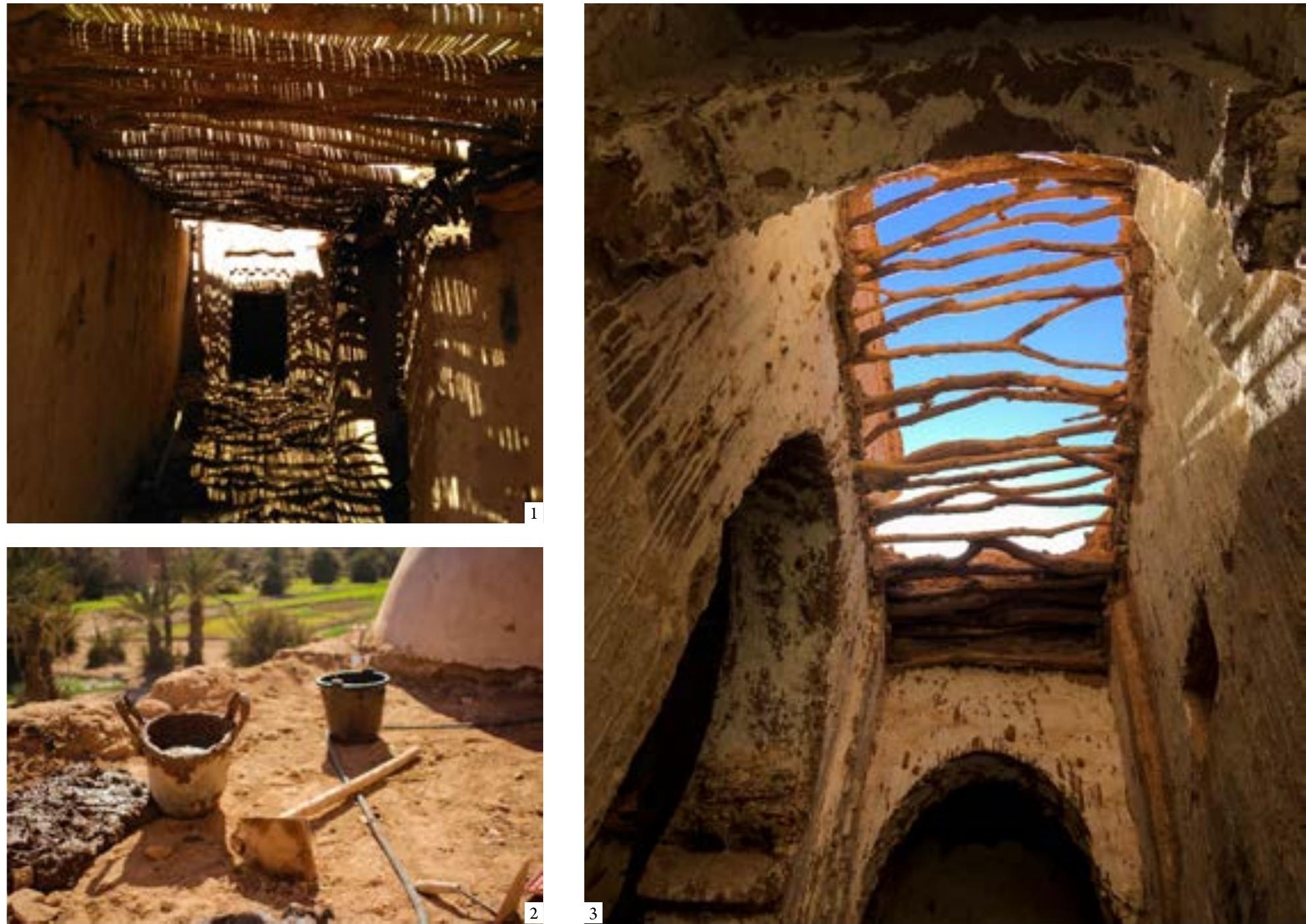

1: Roof construction with tamarisk branches and reed mats 2: Last layer of mud on the roof 3: Tamarisk branches of the roof of the Marabout before restoration | 1: Construcción del techo con vigas de tamarisco y esteras de caña 2: Última capa de barro en el techo 3: Vigas de tamarisco de la cubierta del Morabito antes de la restauración | 1: Construção do teto com vigas de tamarisco e esteiras de cana 2: Última camada de barro no teto 3: Vigas de tamarisco da cobertura do Marabu antes da restauração

With this task complete, the roof of the main shrine could be safely reached with just a ladder. The two most damaged sections of flat roof over this volume (south and west), beyond simple repair, were demolished and rebuilt. The building method was as described above, though here the result was more robust, as the span to be covered was shorter.

Once this second platform was also consolidated, with the international participants and most of the local masters and apprentices now in situ, and with the help and oversight of Abdelkader Mahassine, the flaking or hollowed render and the damaged
Terminada esta operación, era ya posible acceder con seguridad a la cubierta del edificio principal con una sencilla escalera de mano. Se demolieron y reconstruyeron entonces los dos tramos con cubierta plana de este volumen que se encontraban más deteriorados y que no podían ser simplemente reparados: el meridional y el occidental. El sistema constructivo utilizado fue el mismo ya descrito, si bien aquí dotado de una mayor solidez, al tener que salvar una luz menor.

Una vez consolidada también esta segunda plataforma, ya incorporados a la obra los participantes internacionales y el grueso de los maestros y los aprendices
Terminada esta operação, já era possível aceder com segurança à cobertura do edifício principal com um simples escadote. Foram demolidos e reconstruídos então os dois lanços com cobertura plana deste volume que se encontravam mais deteriorados e que não podiam ser simplesmente reparados: o meridional e o ocidental. O sistema construtivo utilizado foi o mesmo já descrito, embora aqui dotado com mais solidez, ao ter que salvar uma luz menor.

Uma vez consolidada também esta segunda plataforma, já incorporados na obra os participantes internacionais e a maior parte dos mestres e aprendizes locais, e com a ajuda e supervisão de 

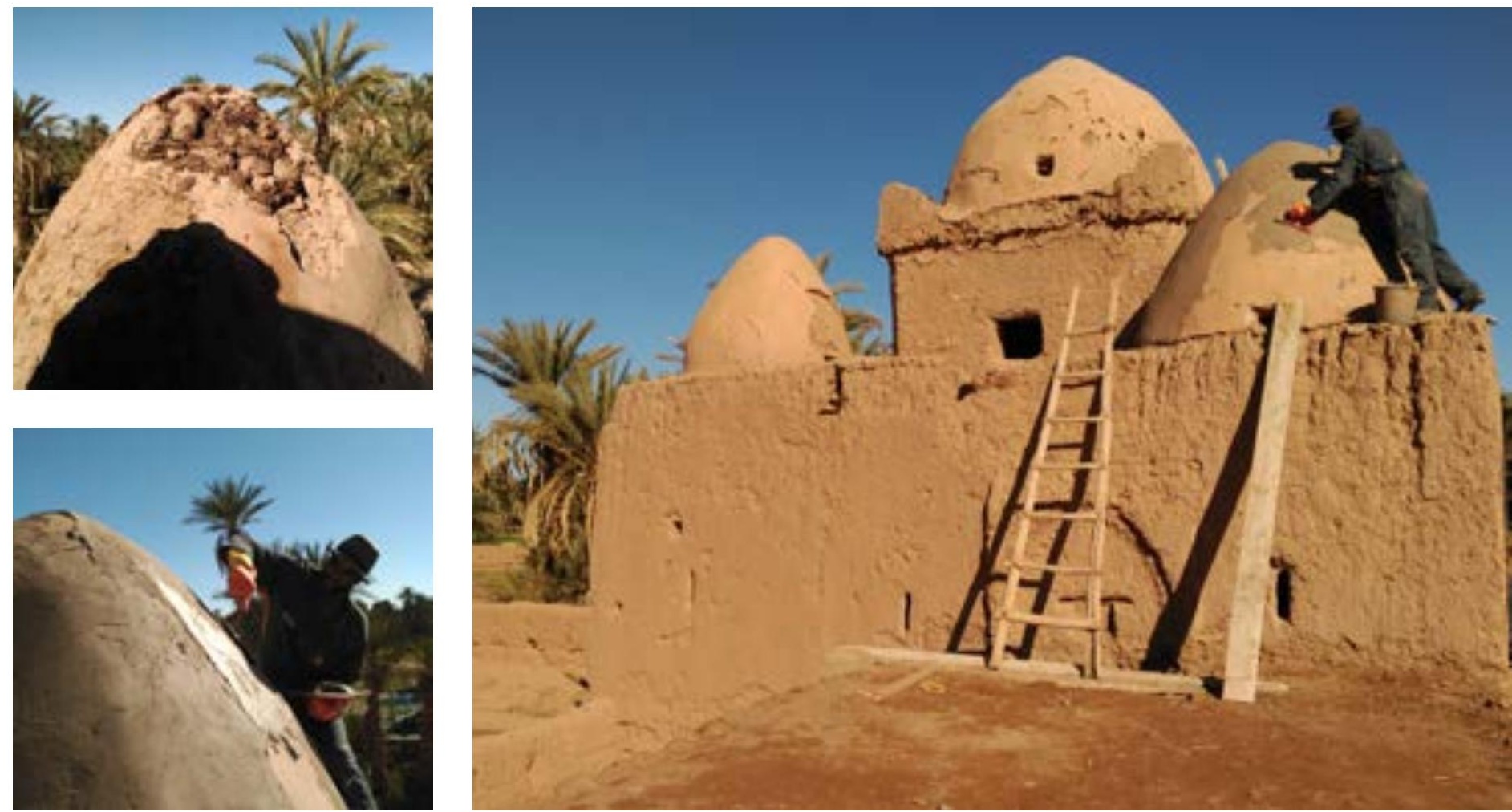

Restoration works of the domes | Trabajos de restauración de las cúpulas | Trabalhos de restauração das cúpulas

adobe in the domes and the crumbling coverings on all the facades were removed and part of the roof parapet was demolished, as it was also damaged and liable to collapse.

The typically problematic points in such buildings were repaired: the jointing between the roof and the parapet, the spout attachments and the slopes for rainwater runoff. The drainage on the roof of the anteroom was improved with conduits made in the wall itself that were coated with lime mortar.

As to the domes, the original volumes were restored with adobe, a layer of mud mortar was applied, and finally they were rendered with lime and sand.

All the facades were covered with two layers of earth and straw mortar: a first rough coat and then a finer surface finish. The lower part of the walls had lost material due to erosion, so the mass was made up using blocks or pieces of adobe. locales, y con la ayuda y la supervisión de Abdelkader Mahassine, se retiraron los revocos desprendidos o ahuecados y los adobes deteriorados de las cúpulas y los revestimientos deteriorados de todas las fachadas y se demolió parte del peto de cubierta, que se encontraba deteriorado y había riesgo de que se cayera.

Se repararon los puntos más problemáticos en este tipo de construcciones: el encuentro de la cubierta con los petos, el arranque de las gárgolas, y las pendientes que evacúen el agua en caso de lluvias. En la cubierta de la antesala meridional la evacuación de aguas se reforzó mediante acanaladuras en el propio muro que se revistieron con mortero de cal.

En cuanto a las cúpulas, se restituyó con adobe su volumen original, se aplicó una capa de mortero de barro y, finalmente, un revoco de cal y arena.

Todas las fachadas fueron revestidas con morteros de tierra y paja compuestos por dos capas: un enfoscado inicial más rugoso y un revoco de terminación
Abdelkader Mahassine, retiraram-se os rebocos desprendidos ou esburacados e os adobes deteriorados das cúpulas e os revestimentos deteriorados de todas as fachadas e demoliu-se parte da platibanda da cobertura, que se encontrava deteriorado e havia o risco de ruína.

Repararam-se os pontos mais problemáticos neste tipo de construções: o encontro da cobertura com as platibandas, o arranque das gárgulas, $\mathrm{e}$ as vertentes que evacuam a água no caso de chuva. $\mathrm{Na}$ cobertura da antecâmara meridional a evacuação das águas reforçou-se mediante caneluras na própria parede que se revestiram com argamassa de cal.

Em relação às cúpulas, o seu volume original foi restituído com adobe, aplicou-se uma camada de argamassa de barro e, por último, um reboco de cal e areia.

Todas as fachadas foram revestidas com argamassa de terra e palha compostas por duas camadas: um reboco fosco inicial mais rugoso e um reboco de acaba- 
The portal was also restored. Its decorative relief was renovated with mud mortar and a lime finish.

Inside the marabout a $90 \mathrm{~cm}$ plinth covering was made with lime mortar and finished with colorless tadelakt so as to protect the lower part of the walls. Tadelakt is a lime-based interior render whose surface is painstakingly smoothed, polished and finally waterproofed and rubbed over with black soap. de superficie más cuidada. Las partes inferiores de los muros exteriores presentaban pérdidas de material debido a la erosión, por lo que se reintegró su masa utilizando adobes o fragmentos de adobes.

La portada de acceso fue también restaurada. Se recuperó el relieve de su decoración con mortero de barro y una terminación de cal.

En el interior del morabito, se realizó un zócalo de 90 centímetros de altura con mortero de cal y acabado de tadelakt sin coloración, con el fin de proteger la parte inferior de los muros. El tadelakt es un tipo de acabado interior a base de cal cuya superficie es cuidadosamente alisada, pulida y finalmente impermeabilizada y terminada con jabón negro. mento de superfície mais cuidado. As partes inferiores das paredes exteriores apresentavam perdas de material devido à erosão, pelo que se reintegrou a sua massa utilizando adobes ou fragmento de adobes.

A portada de acesso também foi restaurada. O relevo da sua decoração foi recuperado com argamassa de barro e um acabamento de cal.

No interior do marabu, realizou-se um embassamento de 90 centímetros de altura com argamassa de cal e um acabamento de tadelakt sem coloração, a fim de proteger a parte inferior dos muros. O tadelakt é um tipo de acabamento interior à base de cal cuja superfície é cuidadosamente alisada, polida e por fim impermeabilizada e terminada com sabão negro.

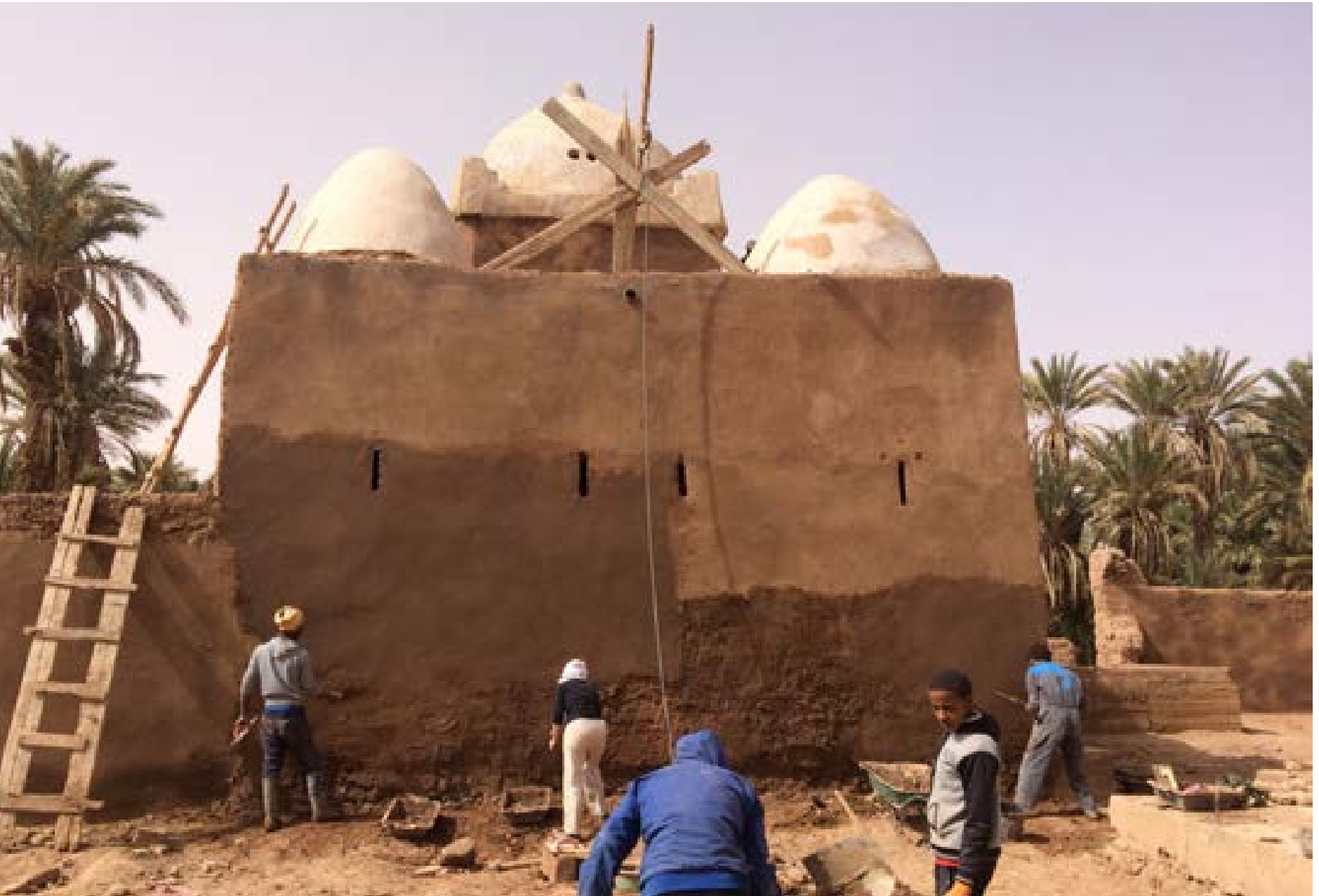



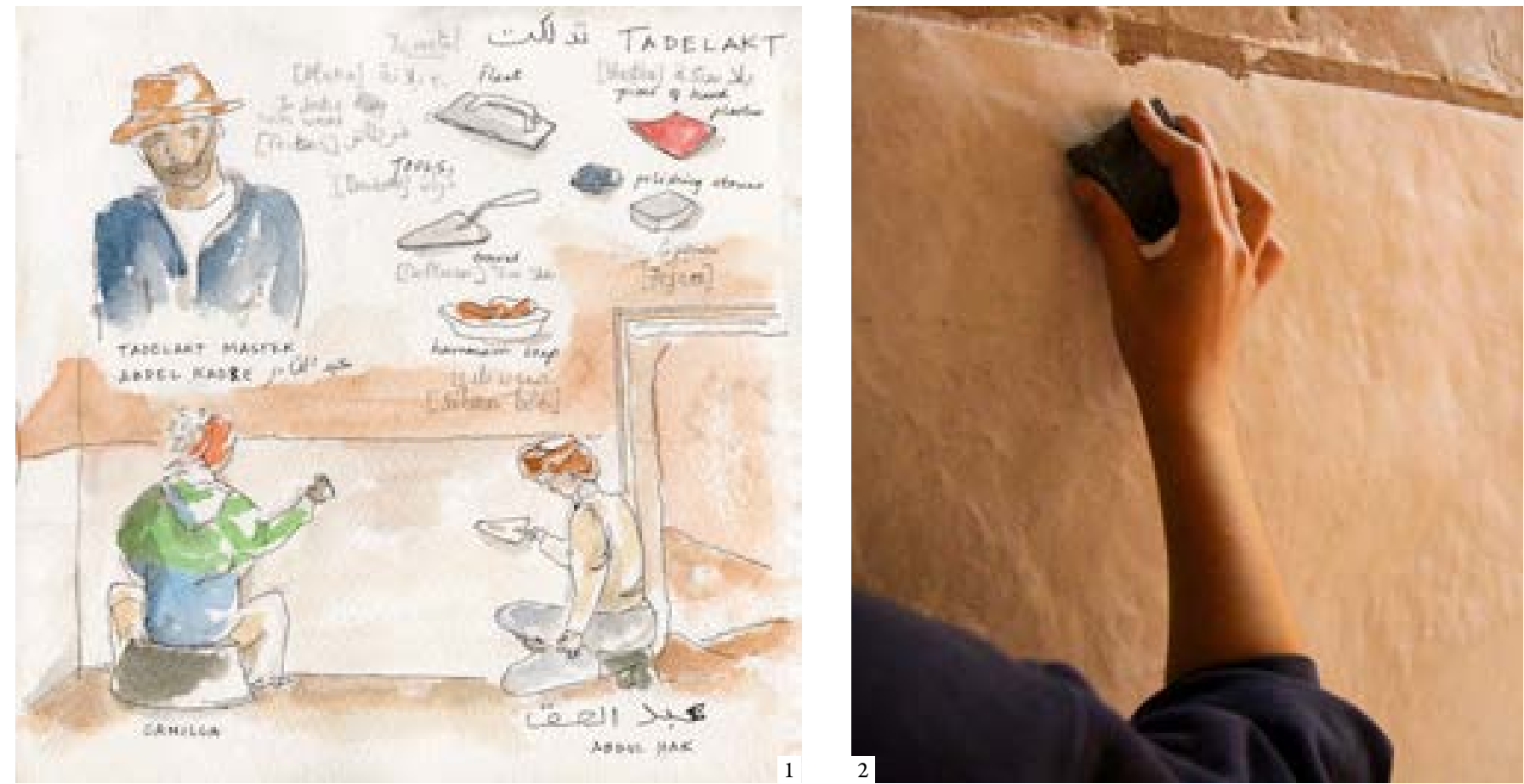

1: Sketch on the tadelakt technique 2: Tadelakt application | 1: Dibujo sobre la técnica del tadelakt 2: Aplicación del tadelakt | 1: Desenho sobre a técnica do tadelakt 2: Aplicação do tadelakt (1: Amanda Roelle)

The upper part of the inner walls was treated with lime water, a translucent glaze that cleanses, consolidates and sanitizes them, without hiding the soot stains attesting to the use made of the shrine.

We also worked on the public space in the marabout's vicinity. The aim was to enhance the character of the ensemble as a 'precinct'. The space was delimited by means of rebuilding the perimeter walls that had been lost or ruined. They were rebuilt with rammed earth one cubit thick and just one course high and rendered with earthen mortar. We also created comfortable and shady areas, as this is a busy spot on account of the water tank, and we levelled the terrain, which was highly uneven due to the half-ruined walls. Finally we planted palm trees so as to create a pleasanter environment and to encourage future maintenance.
En la parte superior de los muros interiores se dio un agua de cal, una veladura translúcida que limpia, consolida e higieniza el espacio, pero no oculta las ya mencionadas manchas de hollín que atestiguan y explican el uso que ha tenido el edificio.

Además, se trabajó sobre el espacio público del entorno del morabito. Se buscó con ello potenciar la lectura del carácter de "recinto" del conjunto. Se delimitó el espacio libre levantando muros perimetrales que se habían perdido o se encontraban arruinados. Estos muros se realizaron con tapiales de un codo de sección y una sola hilada de altura y se revocaron con mortero de tierra. Se crearon también espacios de estancia y de sombra, pues se trata de un espacio concurrido por la presencia del depósito de agua, y se niveló el terreno de la parcela, en el que existían importantes desniveles por la ruina parcial de algunos muros. Finalmente, se plantaron palmeras con el fin de crear un entorno más agradable y favorecer su mejor mantenimiento futuro.
Na parte superior das paredes interiores deu-se uma água de cal, uma veladura translúcida que limpa, consolida e higieniza o espaço, mas não oculta as já mencionadas manchas de fuligem que testemunham e explicam o uso que o edifício teve.

Para além disso, trabalhou-se sobre o espaço público do entorno do marabu. Procurou-se com isso potenciar a leitura do carácter de "recinto" do conjunto. Delimitou-se o espaço livre levantando paredes perimetrais que se tinham perdido ou se encontravam arruinadas. Estas paredes realizaram-se com taipais de um côvado de secção e apenas una fiada de altura e foram rebocadas com argamassa de terra. Também se criaram espaços de estadia e de sombra, pois trata-se de um espaço concorrido pela presença do depósito de água, e nivelou-se o terreno da parcela, no que existiam desníveis consideráveis pela ruina parcial de algumas paredes. Por último, plantaram-se palmeiras com o objetivo de criar um entorno mais agradável e favorecer a sua melhor manutenção futura. 


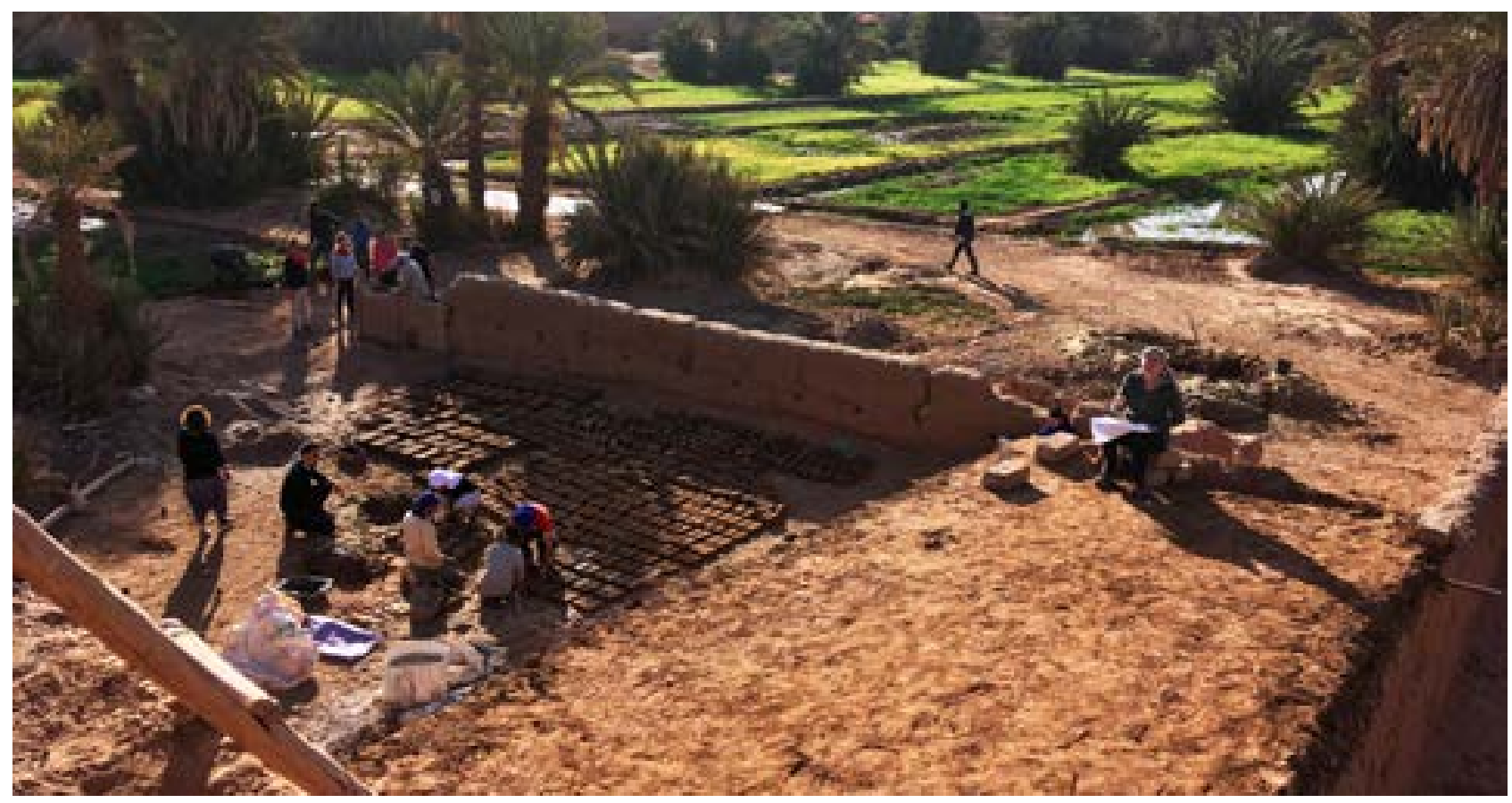

Participants and local masters working together on the restoration of the Marabout | Participantes y maestros locales trabajando en la restauración del Morabito | Participantes e mestres locais a trabalharem na restauração do Marabu

\section{Impact on the oasis and conclusions}

Beyond the restoration of the architectural feature, the project has had repercussions at various levels:

- Social impact: the project model, setting out from dialog with a local population that is involved both in the decisions taken and in the performance of the work (with masters and apprentices), reinforces collective cultural identity. The enhanced habitability of the restored space and the very attention paid both to the place and to its traditions also help raise local people's awareness of the importance of preserving their heritage (architecture, landscape, inherited knowledge, etc.).

- Economic impact: thanks to our commitment to traditional local techniques, $50 \%$ of the overall project budget was spent directly on the wages of masters and apprentices, and just $15 \%$ on materials, $20 \%$ on overheads at the oasis and $15 \%$ on the Terrachidia structure. With the use of non-imported local materials (unlike reinforced concrete, prefabricated blocks or other such materials manufactured at a distance) and the
Impacto en el oasis y conclusiones finales

Más allá de la propia restauración del elemento arquitectónico la intervención ha tenido impacto a distintos niveles:

Impacto social: el modelo de intervención que parte del diálogo con la población local, que es integrada tanto en la toma de decisiones como en el propio desarrollo de la obra (maestros y aprendices) refuerza la identidad cultural colectiva. Además, la mejora en las condiciones de habitabilidad del espacio recuperado y la propia atención prestada tanto al lugar como a sus tradiciones contribuyen a concienciar a la población sobre la importancia de conservar su patrimonio (la arquitectura, el paisaje, el conocimiento heredado, etc.).

- Impacto económico: gracias a la apuesta por técnicas locales artesanales, el 50\% del presupuesto global del proyecto se ha destinado directamente a los sueldos de los maestros y los aprendices, sólo un $15 \%$ a los materiales, un 20\% a los gastos indirectos generados en el propio oasis y un $15 \%$ a la propia estructura de Terrachidia. Al utilizar materiales locales y no importados (como sería
Impacto no oásis e conclusões finais

Mais além da própria restauração do elemento arquitetónico a intervenção teve um impacto a vários níveis:

Impacto social: o modelo de intervenção que parte do diálogo com a população local, que é incluída tanto na tomada de decisões como no próprio desenvolvimento da obra (mestres e aprendizes) reforça a identidade cultural coletiva. Adicionalmente, a melhoria das condições de habitabilidade do espaço recuperado e da própria atenção prestada, tanto ao lugar como às suas tradições contribuem para sensibilizar a população sobre a importância de conservar o seu património (a arquitetura, a paisagem, o conhecimento herdado, etc.).

- Impacto económico: graças à aposta pelas técnicas locais artesanais, 50 $\%$ do orçamento global do projeto foi destinado diretamente ao salário dos mestres e dos aprendizes, apenas um $15 \%$ aos materiais, um $20 \%$ aos gastos indiretos gerados pelo próprio oásis e um $15 \%$ à própria estrutura de Terrachidia. Ao utilizar materiais locais e não importados (como seria o caso do 
choice of building solutions devised on site rather than brought in ready-made, most of the project budget goes on generating quality local employment and supporting a circular economy at the oasis. This provides broad benefits for local living conditions, as opposed to other forms of building in which much of the money invested ends up leaving the oasis and even the country.

- Environmental impact: given that the materials used in the work are all from the region, mostly from the oasis itself and some, such as earth, from the actual site, the impact of their transportation on the environment is virtually zero. These are also recyclable and infinitely reusable materials, and as regards earth and wood, also reused here. Even the most processed material - lime, used only in places and in small proportions - has a quite low environmental impact as compared to the high emissions produced by cement. So the work did not and will not generate any waste, or jeopardize the oasis's fragile environmental balance.

Terrachidia's methods, giving priority to traditional building materials and techniques in its projects and recovering the figures of master and apprentice, included in each project as a key part of the process, have proven to be effective not just in restoring the tangible and intangible heritage of a place but also in helping maintain its social, economic and environmental balance.

As well as the work on the marabout itself, it is worth noting the documentation and dissemination of the place's heritage resulting from Terrachidia's partnership with ArCHIAM, notably including the production of the documentary M'hamid Oasis Morocco: Restoring, Recording and Inventorying the Tangible and Intangible Cultural Heritage, directed by Monika Koeck, and the el caso del hormigón armado, los bloques prefabricados u otros materiales elaborados fuera de la zona), y optar por soluciones constructivas que se producen en la propia obra y no llegan ya preparadas de fábrica, la mayor parte del presupuesto se destina a generar empleo de calidad en el propio lugar y a reforzar la economía circular del oasis. Esto se traduce en una mejora general de las condiciones de vida de la población, frente a otras formas de construir en las que buena parte de la inversión económica escapa del oasis, e incluso del país.

- Impacto medioambiental: dado que los materiales utilizados en la obra proceden todos de la región, casi todos ellos del propio oasis y algunos, como la tierra, de la propia parcela en la que se trabajó, el impacto que tiene su transporte sobre el medioambiente es prácticamente nulo. Se trata además de materiales reciclables e infinitamente reutilizables $y$, en el caso de la tierra y la madera, de hecho, también reutilizados. Incluso el más procesado de ellos, la cal, utilizada sólo de forma puntual y en baja proporción, tiene un impacto medioambiental bastante bajo cuando se compara con las altas emisiones producidas por el cemento. La obra no generó ni generará, por tanto, residuo alguno y el frágil equilibrio medioambiental del oasis no se verá amenazado por ella.

La metodología de Terrachidia, con el empleo prioritario de materiales y técnicas tradicionales de construcción en sus obras, y con la recuperación de las figuras del maestro y el aprendiz, que se incorporan a cada obra como un elemento esencial del proceso, demuestra ser una forma eficaz de recuperar no sólo el patrimonio material e inmaterial de un lugar, sino de contribuir a mantener su equilibrio social, económico y medioambiental.

Como complemento a la intervención en el propio morabito es importante señalar los trabajos de documentación betão armado, os bloques pré-fabricados ou outros materiais elaborados fora da zona), e optar por soluções construtivas que se produzem na própria obra e que não chegam já preparadas de fábrica, a maior parte do orçamento destinase a criar emprego de qualidade no próprio lugar e a reforçar a economia circular do oásis. Isto traduz-se numa melhoria geral das condições de vida da população se comparado com outras formas de construir nas que boa parte do investimento económico escapa ao oásis, e inclusive ao país.

Impacto ambiental: dado que os materiais utilizados na obra provêm todos da região, quase todos do próprio oásis e alguns, como a terra, do próprio terreno que foi lavrada, o impacto que tem o seu transporte sobre o meio ambiente é praticamente nulo. Tratase também de materiais recicláveis e infinitamente reutilizáveis e, no caso da terra e da madeira foram em realidade também reutilizados. Inclusive $\mathrm{o}$ mais processado deles, a cal, utilizada apenas de forma esporádica e em baixa proporção, tem um impacto ambiental bastante baixo quando comparada com as altas emissões produzidas pelo cimento. A obra não gerou nem gerará, portanto, qualquer resíduo e o frágil equilíbrio ambiental do oásis não se verá ameaçado pela mesma.

A metodologia de Terrachidia, com o emprego prioritário de materiais e técnicas tradicionais de construção nas suas obras, e com a recuperação da imagem do mestre e do aprendiz, que se integraram a cada obra como um elemento essencial do processo, demonstra ser uma forma eficaz de recuperar não só o património material e imaterial de um lugar, mas também a de contribuir para manter o seu equilíbrio social, económico e ambiental.

Como complemento à intervenção no próprio marabu é importante salientar os trabalhos de investigação e difusão 
publication of the book Ouled Youssef, an old ksar in the M'hamid Oasis (INTBAU Spain, 2021), thanks to funding from the Barakat Trust and Liverpool University. These activities are part of a range of outreach and awareness actions deployed alongside Terrachidia's projects at the M'hamid Oasis, including the holding of seminars, meetings and exhibitions at the oasis and elsewhere and various publications on the local heritage and the work done.

A year and a half after its restoration, the marabout is in perfect condition and the locals from the nearby ksur are able to enjoy a pleasanter and better cared for site and environment on their visits there.

Exterior of the restored domes | Exterior de las cúpulas restauradas | Exterior das cúpulas restauradas y de difusión del patrimonio del lugar desarrollados como fruto de la colaboración de Terrachidia con ArCHIAM, entre los que podemos destacar la producción del documental M'hamid Oasis Morocco: Restoring, Recording and Inventorying the Tangible and Intangible Cultural Heritage, dirigido por Monika Koeck, y la publicación del libro Ouled Youssef, an old ksar in the M'hamid Oasis (INTBAU España, 2021), gracias a la financiación del Barakat Trust y la Universidad de Liverpool. Estas actividades se integran en el conjunto de actuaciones de difusión y sensibilización implementados junto con los proyectos de Terrachidia en el oasis de Mhamid, que han incluido la organización de seminarios, encuentros y exposiciones tanto en el oasis como fuera de él y diversas publicaciones sobre el patrimonio local y los trabajos realizados.

Un año y medio después de su restauración, el morabito está en perfecto estado y los vecinos de los ksur cercanos pueden disfrutar de un entorno y un espacio más cuidados y agradables en sus visitas al lugar. do património do local desenvolvidos como fruto da colaboração de Terrachidia com ArCHIAM, entre os que podemos destacar a produção documental M'hamid Oasis Morocco: Restoring, Reccording and Interventorying the Tangible and Intangible Cultural Heritage, dirigido por Monika Koeck, e a publicação do livro Ouled Youssef, an old ksar in the M'hamid Oasis (INTBAU Espanha, 2021), graças ao financiamento do Barakat Trust e da Universidade de Liverpool. Estas atividades integram-se no conjunto de ações de difusão e sensibilização implementados em conjunto com os projetos de Terrachidia no oásis de Mhamid, que incluíram a organização de seminários, encontros e exposições tanto no oásis como fora deste e diversas publicações sobre o património local e dos trabalhos realizados.

Ano e meio depois da sua restauração, o marabu está em perfeito estado e os vizinhos dos ksur cercanos podem apreciar um entorno e um espaço mais cuidado e agradável nas suas visitas ao local.

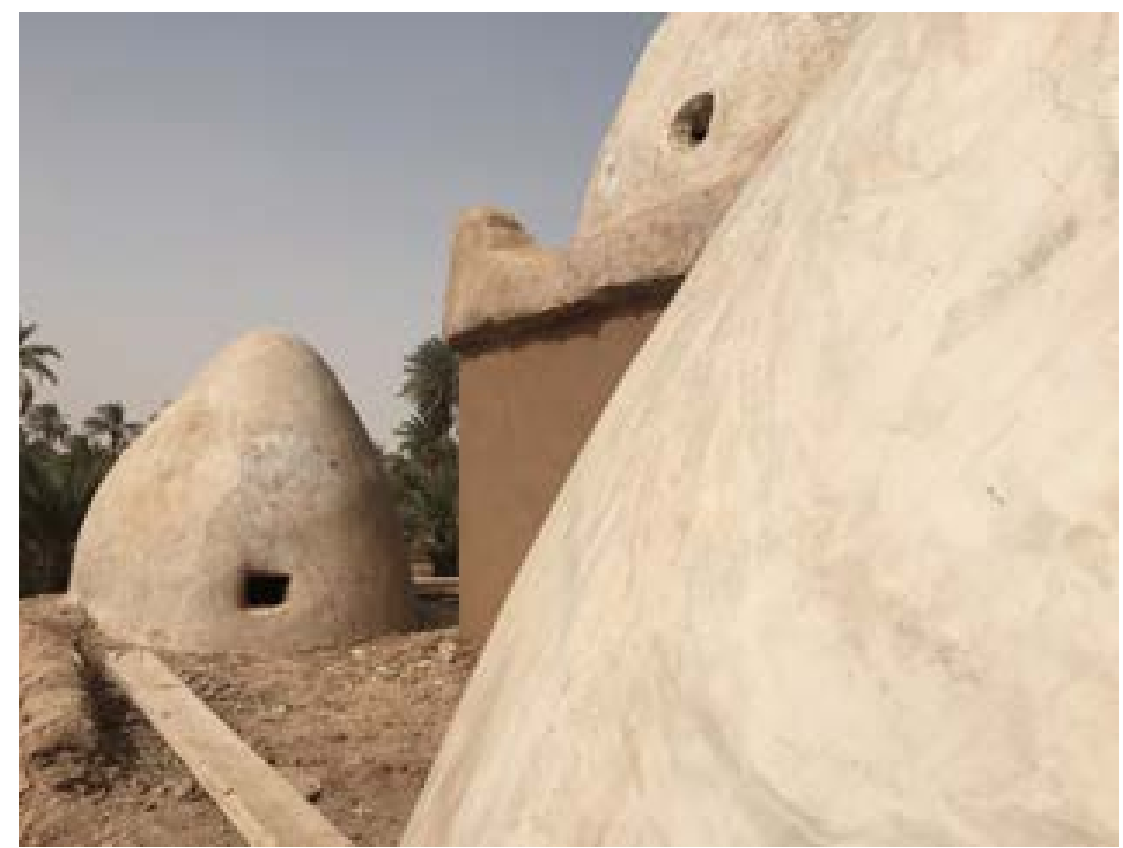




\section{Biographies | Biografías | Biografias}

\section{Marta Colmenares Fernández}

Architect, MSc in Land Planning and Management (Urban Studies) specializing in Development of Informal Human Settlements at the Madrid Polytechnic University School of Architecture. She has worked for more than 15 years in architecture, cataloguing of architectural and urban heritage and urban planning, and has been involved in various development and basic-housing projects since 2007. She has been a guest speaker at various international courses, congresses and seminars and is often invited to lecture on aspects of basic housing and development cooperation at the Madrid Polytechnic University School of Architecture. She is a member of the board of the NGO Terrachidia, whose work has been honored with the INTBAU Excellence Award 2015 and the Prix européen d'architecture Philippe Rotthier 2021.

Es Arquitecta, Máster en Planeamiento y Ordenación del Territorio (Estudios Urbanos) y Especialista en Desarrollo de Asentamientos Humanos Precarios por la Escuela Técnica Superior de Arquitectura de la Universidad Politécnica de Madrid. Lleva más de 15 años trabajando en arquitectura, en catalogación del patrimonio arquitectónico y urbano y en planificación urbana y ha estado vinculada a diversos proyectos de desarrollo y habitabilidad básica desde el año 2007. Ha sido conferenciante invitada en distintos cursos, congresos y seminarios internacionales y es regularmente invitada como docente en materias de habitabilidad básica y cooperación en la Escuela Técnica Superior de Arquitectura de la Universidad Politécnica de Madrid. Es miembro de la Junta Directiva de la ONG Terrachidia, cuyo trabajo ha recibido el INTBAU Excellence Award 2015 y el Prix Européen d’Architecture Philippe Rotthier 2021.

É arquiteta, mestre em Planeamiento y Ordenación del Territorio (Estudios Urbanos) e especialista em Desarrollo de Asentamientos Humanos Precarios pela Escola Técnica Superior de Arquitectura da Universidade Politécnica de Madrid. Há mais de 15 anos que trabalha em arquitetura, na catalogação do património arquitetónico e urbano e na planificação urbana e esteve vinculada a diversos projetos de desenvolvimento e habitabilidade básica desde 2007. Foi convidada como conferencista em diversos cursos, congressos e seminários internacionais e é regularmente convidada como docente em matérias de habitabilidade básica e cooperação na Escola Técnica Superior de Arquitectura da Universidade Politécnica de Madrid. É membro do Conselho Diretivo da ONG Terrachidia, cujo trabalho recebeu o INTBAU Excellence Award 2015 e o Prix Européen d'Architecture Philippe Rotthier 2021.

\section{Alejandro García Hermida}

He is an Associate Professor at the Department of Architectural Composition of the Escuela Técnica Superior de Arquitectura of the Universidad Politécnica de Madrid, graduated in Architecture and holds a PhD from the same university, and has been a Visiting Scholar at the School of Architecture of the University of Notre Dame. His professional practice has been focused on traditional architecture and construction and the restoration and study of historic buildings. He is the Executive Director of the INTBAU Initiatives in Spain and Portugal, member of the Board of Terrachidia NGO; and Vice Chair of INTBAU Spain. Some of these works have been awarded the 2015 INTBAU Excellence Award, the 2019 Hispania Nostra Award, a Special Mention from the 2019 Europa Nostra Awards and the 2021 Prix Européen d'Architecture Philippe Rotthier.

Es Profesor Asociado del Departamento de Composición Arquitectónica de la Escuela Técnica Superior de Arquitectura de la Universidad Politécnica de Madrid, Doctor Arquitecto por la misma universidad, y ha sido Visiting Scholar en la Escuela de Arquitectura de la Universidad de Notre Dame. Ha dedicado su actividad profesional a la arquitectura y la construcción tradicionales y a la restauración y el estudio de edificios históricos. Es Director Ejecutivo de las Iniciativas de INTBAU en España y Portugal; miembro de la Junta Directiva de la ONG Terrachidia; y Vicepresidente de INTBAU España. Algunos de estos trabajos han sido galardonados con el INTBAU Excellence Award 2015, el Premio Hispania Nostra 2019, una Mención Especial de los Premios Europa Nostra 2019 y el Prix Européen d’Architecture Philippe Rotthier 2021.

É Professor Associado no Departamento de Composição Arquitectónica pela Escola de Arquitectura da Universidade Politécnica de Madrid, Doutor Arquitecto pela mesma universidade, e foi Visiting Scholar na University of Notre Dame School of Architecture (Indiana, E.U.A.). Dedicou a sua actividade profissional à arquitectura e construção tradicionais e ao restauro e análise histórico-construtiva de edifícios históricos. É director executivo das iniciativas do INTBAU em Espanha e Portugal, membro do Conselho de Administração da ONG Terrachidia e Vice-presidente do INTBAU Espanha. Algumas dessas iniciativas foram premiadas com o INTBAU Excellence Award 2015, o Prémio Hispania Nostra 2019, a menção especial Europa Nostra 2019 e o Prix Européen d'Architecture Philippe Rotthier 2021.

\section{Carmen Moreno Adán}

She is an Architect and holds a Master's in Conservation and Restoration of Architectural Heritage and a Postgraduate Diploma in Development of Precarious Human Settlements from the School of Architecture of the Universidad Politécnica de Madrid. She is an Associate Professor at the Department of Architectural Composition of the Universidad Alfonso X el Sabio, Madrid. She has been a guest lecturer at various conferences and dedicates her professional activity to the recovery and restoration of public spaces and buildings within traditional towns. She is a member of the management committee at the LabOasis Foundation and a member of the board of Terrachidia NGO, whose work has been honoured with the 2015 INTBAU Excellence Award and the 2021 Prix Européen d'Architecture Philippe Rotthier.

Es Arquitecto, Máster en Conservación y Restauración del Patrimonio Arquitectónico y Especialista en Desarrollo de Asentamientos Humanos Precarios por la Escuela Técnica Superior de Arquitectura de la Universidad Politécnica de Madrid. Es profesora del Departamento de Composición Arquitectónica de la Escuela de Arquitectura de la Universidad Alfonso X El Sabio. Ha sido conferenciante invitada en diversos congresos y dedica su actividad profesional a la recuperación y restauración de espacios públicos y edificaciones de ciudades tradicionales. Es miembro del comité directivo de la Fundación LabOasis y miembro de la Junta Directiva de la ONG Terrachidia, cuyo trabajo ha recibido el INTBAU Excellence Award 2015 y el Prix Européen d'Architecture Philippe Rotthier 2021.

Arquiteta, Mestre em Conservação e Restauração do Património Arquitetónico e Especialista em Desarrollo de Asentamientos Humanos Precarios pela Escola Técnica Superior de Arquitetura da Universidade Politécnica de Madrid. É professora do Departamento de Composição Arquitetónica da Escola de Arquitectura da Universidade Alfonso X, El Sabio. Foi convidada como conferencista em diversos congressos e dedica a sua atividade profissional à recuperação e restauração de espaços público e edificações de cidades tradicionais. É membro do comité diretivo da Fundación LabOasis e membro do Conselho Diretivo da ONG Terrachidia, cujo trabalho recebeu o INTBAU Excellence Award 2015 e o Prix Européen d'Architecture Philippe Rotthier 2021. 